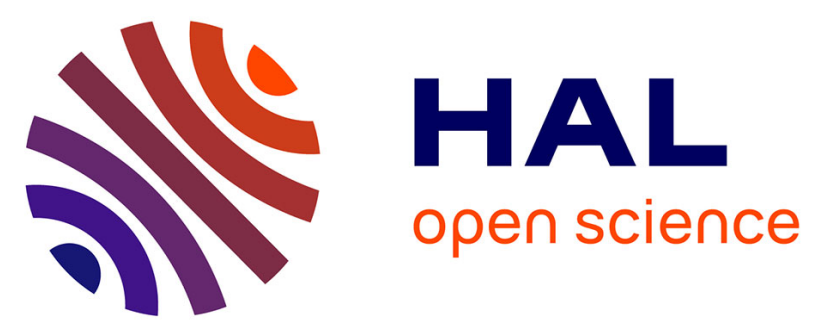

\title{
Evidence for subtropical warmth in the Canadian Arctic (Beaufort-Mackenzie, Northwest Territories, Canada) during the early Eocene
}

\author{
Marie Salpin, Johann Schnyder, François Baudin, Guillaume C Suan, \\ Jean-Pierre Suc, Speranta-Maria Popescu, Séverine Fauquette, Lutz \\ Reinhardt, Mark D Schmitz, Loic Labrousse
}

\section{To cite this version:}

Marie Salpin, Johann Schnyder, François Baudin, Guillaume C Suan, Jean-Pierre Suc, et al.. Evidence for subtropical warmth in the Canadian Arctic (Beaufort-Mackenzie, Northwest Territories, Canada) during the early Eocene. Geological Society of America Special Papers, 2019, Circum-Arctic Structural Events: Tectonic Evolution of the Arctic Margins and Trans-Arctic Links with Adjacent Orogens, 541, $10.1130 / 2018.2541(27)$. hal-02321960

\section{HAL Id: hal-02321960 https://hal.science/hal-02321960}

Submitted on 5 Oct 2020

HAL is a multi-disciplinary open access archive for the deposit and dissemination of scientific research documents, whether they are published or not. The documents may come from teaching and research institutions in France or abroad, or from public or private research centers.
L'archive ouverte pluridisciplinaire HAL, est destinée au dépôt et à la diffusion de documents scientifiques de niveau recherche, publiés ou non, émanant des établissements d'enseignement et de recherche français ou étrangers, des laboratoires publics ou privés. 


\title{
Evidence for subtropical warmth in the Canadian Arctic (Beaufort- Mackenzie, Northwest Territories, Canada) during the early Eocene
}

\author{
Marie Salpin', Johann Schnyder1, François Baudin', Guillaume Suan², Jean-Pierre Suc1, \\ Speranta-Maria Popescu ${ }^{3}$, Séverine Fauquette ${ }^{4}$, Lutz Reinhardt ${ }^{5}$, Mark D. Schmitz ${ }^{6}$, Loic \\ Labrousse $^{1}$ \\ (1) Sorbonne Universités, UPMC Univ. Paris 06, UMR 7193, Institut des Sciences de la Terre Paris (ISTeP), \\ 75005, Paris, France \\ (2) Univ Lyon, Université Lyon 1, ENS-Lyon, CNRS, UMR 5276 LGL-TPE, F-69622, Villeurbanne, France \\ (3) GeoBioStratData Consulting, 385 Route du Mas Rillier, 69140 Rillieux la Pape, France \\ (4) Institut des Sciences de l'Évolution, Université de Montpellier, CNRS, IRD, EPHE, Place Eugène Bataillon, \\ 34095 Montpellier cedex 5, France \\ (5) Federal Institute for Geosciences and Natural Resources (BGR), Stilleweg 2, 30655 Hannover, Germany \\ (6) Isotope Geology Laboratory, Boise State University, 1910 University Drive, Boise, Idaho 83725-1535, USA
}

\begin{abstract}
During the Paleocene-Eocene, the Earth experienced the warmest conditions of the Cenozoic and reduced equator-to-pole temperature gradients. Compared to low- and mid-latitude sites, Paleogene environmental changes are less documented in Arctic regions, although such high latitude areas constitute a critical domain to constrain global climate changes. Floral and faunal assemblages indicative of exceptionally warm and humid conditions during the late Paleocene-early Eocene have been reported in several localities around the Arctic Ocean. Additional studies are required to ascertain the effects of Paleocene-Eocene global environmental changes on western Arctic regions. Here we present multiproxy data from early Eocene deltaic plain sediments of the Mackenzie Delta (Canada). This environment is characterized by littoral forest, including swamp, showing that the mangrove Avicennia grew in Arctic Canada near $75^{\circ} \mathrm{N}$ under air temperatures averaging $21-22{ }^{\circ} \mathrm{C}$ annually and 10-14 ${ }^{\circ} \mathrm{C}$ in winter and with precipitation of $1200-1400$ $\mathrm{mm} / \mathrm{yr}$. Kaolinite contents are high (up to $75 \%$ of clay assemblages), as under a modern subtropical climate. The Avicennia pollens recently found in the New Siberian Islands and in Arctic Canada imply that warm and wet conditions were widespread along the Arctic coast during the early Eocene. It also suggests a marine connection between the Arctic Basin and the mid-latitude oceans. We propose that an oceanic current must have connected the Arctic Basin to the Atlantic and/or Pacific and that an internal current developed in the Arctic Basin since the early Eocene.
\end{abstract}

\section{INTRODUCTION}

The Paleocene to early Eocene has been recognized as the warmest period of the Cenozoic Era. Paleocene-Eocene global warming began in the late Paleocene and continued into the early Eocene (58-50 Ma; Vandenbergh e et al., 2012), reaching an optimum in the early Eocene (52$50 \mathrm{Ma}$; Zachos et al., 2001; Vandenberghe et al., 2012). This time interval is punctuated by several short-lived (150-200 ky) hyperthermal events (Aubry et al., 2003; Röhl et al., 2007), the greatest in magnitude being the Paleocene-Eocene Thermal Maximum (PETM, $56 \mathrm{Ma}$ ) and the Eocene Thermal Maximum 2 (ETM2, 2 My after the PETM) (Zachos et al., 2001; Brinkhuis et al., 2006; Thomas, 2008; Stap et al., 2010; Storme et al., 2012a; Garel et al., 2013).

During these hyperthermal events, the global average temperature rose by as much as $8{ }^{\circ} \mathrm{C}$ above pre-event values (Zachos et al., 2001; Jones et al., 2013). These extreme global warming events are systematically associated with negative carbon isotope excursions (CIE) in both marine and terrestrial carbonate ( $-3 \%$ ) as well as in organic carbon ( $\sim 6 \%$, e.g., Aubry et al., 2007; Storme et al., 2012b), which is thought to refl ect the massive release of isotopically light carbon dioxide and methane into the ocean and atmosphere carbon pools (Kennett and Stott, 1991; Pearson and Palmer, 2000; Zachos et al., 2001, 2008; Lourens et al., 2005; Schouten et al., 2007; DeConto et al., 2012). These late Paleocene and early Eocene hyperthermal events 
induced major turnovers in the assemblage of planktonic and benthic foraminifera, calcareous nannofossils, and dinoflagellates, with an especially pronounced increase in the relative abundance of the dinoflagellate genus Apectodinium during the PETM (Kennett and Stott, 1991; Kaiho et al., 1996; Thomas et al., 2000; Crouch et al., 2003; Zachos et al., 2005). These biotic changes coincided with major changes in ocean and atmosphere circulations and repeated pulses of lysocline and carbonate compensation depth shoaling (Zachos et al., 2005; Schouten et al., 2007).

Extensive paleobotanic studies have been performed in the Paleogene sediments of the Arctic domain. Many of them were based on plant macroremains with identifications most often at the genus level, establishing that many of the modern botanical genera already existed in Paleogene times (e.g.: Basinger et al., 1994; Greenwood and Basinger, 1994; Jahren, 2007; McIver and Basinger, 1999; Sunderlin et al., 2011; Eberle and Greenwood, 2012; Eldrett et al., 2014; West et al., 2015; Harrington et al., 2011; and older references). Simultaneously, studies based on pollen grain identification under the transmitted light microscope developed an identification approach mixing the artificial and botanic nomenclatures (Ridgway et al., 1995; Kalkreuth et al., 1996; Frederiksen et al., 2002; White, 2006; Sluijs et al., 2009). The result was a taxonomic gap between macroremain and pollen floras. Palynologists have put forth serious efforts in botanical identification aimed at reducing and closing this gap, first using only the transmitted light microscope (Eldrett et al., 2009; Barke et al., 2011; Harrington et al., 2011; Zaporozhets and Akhmetiev, 2013), then with the scanning electronic microscope (Liu and Basinger, 2000; Grimsson et al., 2014; Suan et al., 2017). The IODP-ACEX wells (2004) were cored on the Lomonosov Ridge in the central Arctic Ocean in order to increase information thanks to a long and continuous record (Moran et al., 2006; Sluijs et al., 2008; Backman and Moran, 2009). The results from the ACEX expedition indicate euxinic conditions and high primary productivity in the central Arctic Ocean during the Paleogene and early Eocene (Stein et al., 2006). Tetraether lipid based proxies (TEX86 and MBT) revealed an increase of air and sea surface temperatures (SST) of up to $8{ }^{\circ} \mathrm{C}$ during the PETM (Sluijs et al., 2006, 2009; Weijers et al., 2007) and a subsequent $3-5^{\circ} \mathrm{C} \mathrm{SST}$ warming during the ETM2 (Sluijs et al., 2009). On the Siberian margin, floral assemblages indicate a paratropical humid climate (Akhmetiev and Beniamovski, 2009; Suan et al., 2017). Floral and faunal assemblages indicative of exceptionally warmer and more humid conditions during the late Paleocene-early Eocene than today have been also reported in other localities around the Arctic Ocean (Ellesmere Island, e.g., Eberle et al., 2010; Schubert et al., 2012; Northeast Yukon, Vavrek et al., 2012; Axel Heiberg Island, e.g., McIver and Basinger, 1999; Northwest Territories (NWT), Ellesmere and Axel Heiberg Islands: Greenwood et al., 2010; Canadian Arctic: Eberle and Greenwood, 2012; Alaska: Sunderlin et al., 2011). Although these studies have provided valuable constraints for climate conditions in the Arctic during the Paleocene-Eocene, they are limited to a few localities (Fig. 1). Therefore, additional studies are required to ascertain the effects of Paleocene-Eocene global environmental changes on western Arctic regions.

This study aims to constrain paleoclimatic conditions of the Canadian margin during the Paleocene-Eocene. We focus on the Mackenzie Delta of the Beaufort-Mackenzie Basin in the Arctic Basin with a multiproxy approach comprising organic matter characterization, clay mineralogy, comprehensive botanical palynology, and carbon isotope geochemistry on dispersed organic matter.

\section{GEOLOGICAL SETTING AND SAMPLES}

The Mackenzie Delta lies north of the Arctic Circle $\left(68-69^{\circ} \mathrm{N}\right)$, on the coastline of the Northwest Territories, Canada (Fig. 1). This fluvial-dominated delta is $200 \mathrm{~km}$ long, and $80 \mathrm{~km}$ wide, oriented along a NNW axis (Dixon, 1986), and was located at a paleolatitutde of $\sim 75^{\circ} \mathrm{N}$ 
during the Eocene (van Hinsbergen et al., 2015). A high sedimentation rate has been recorded in the Beaufort-Mackenzie Basin, with Cretaceous to Cenozoic deposits being 12-16 km thick (Dixon, 1992). The Cenozoic strata have been penetrated by many petroleum wells but are rarely exposed in outcrops. The most extensive outcrops are found along the Caribou Hills on the eastern part of the Mackenzie Delta (Fig. 1). Based on outcrop and well data, twelve transgressive-regressive sedimentary sequences have been recognized within Upper Cretaceous to Quaternary sedimentary succession in the Beaufort-Mackenzie Basin, each sequence being bounded by major unconformities (Dixon et al., 2008). The basin infill seems partly controlled by the local tectonic activity, at least until the late Miocene. The major tectonic pulses of deformation in the region spanned from Paleocene to Miocene during the development of the Canadian Cordillera ending to the North in the Richardson Mountains (Fig. 1) and the Brooks Range-British Mountains belt along the Arctic Ocean ending offshore with the Beaufort Fold Belt (Harrison et al., 1999; Dixon et al. 2008). The dating of these sedimentary sequences is based on the identification of foraminiferal and palynological assemblages (spore, pollen grains, and dinoflagellate cysts; McNeil, 1989; Dixon, 1992).

The Paleogene strata constitute a series of predominantly delta plain deposits made up of unconsolidated sandy to gravel sedimentary packages corresponding to fluvial channel belts, as well as groups of shaly horizons indicative of levee or deltaic plain environment, and occasional thin coal beds of wetland environment (Price et al., 1980).

The occurrence of the benthic foraminifera Reticulophragmium sp. at the base of the sequence and the associations of pollen grains, dinoflagellates, and foraminifera above led to the assignment of $720 \mathrm{~m}$ out of the total $1200 \mathrm{~m}$ of Cenozoic strata exposed at Caribou Hills to the late Paleocene-middle Eocene Aklak and Taglu depositional sequences (Parsons, 2000; Fig. 2). The rest of the Cenozoic succession is thought to be Oligocene to Pliocene in age (Kugmalitt to Iperk sequences; Parsons, 2000). The boundary between Aklak and Taglu sequences is marked by an angular unconformity, which is well documented in seismic data but difficult to observe on outcrops (Dixon, 1992).

For this study, two sections have been sampled along the Caribou Hills exposure during the CASE 15 (Circum-Arctic Structural Events) expedition in 2013 by L. Labrousse (ISTeP, France) and L. Reinhardt (BGR, Germany). These two sections are $26 \mathrm{~m}$ thick $(\mathrm{CaH} 1)$ and 50 $\mathrm{m}$ thick (CaH2) and belong to the Taglu and/or Aklak sequence. $\mathrm{CaH} 2$ is estimated to be stratigraphically ca. $400 \mathrm{~m}$ above $\mathrm{CaH} 1$. The $\mathrm{CaH} 1$ section is mainly composed of silty clays more or less rich in organic matter, which are interrupted by three sandy levels at the base of the section. A bentonite layer occurs at $23 \mathrm{~m}$, which is characterized by its prominent orange color when weathered. It consists mainly of smectite with some traces of goethite and gypsum. The fresh unweathered bentonite of the $\sim 10 \mathrm{~cm}$ thick layer has a light beige color. Above this layer, an additional set of $\sim 4 \mathrm{~cm}$ thick, orange bentonite layers are preserved in a sequence of brownish siltstones. The horizontally bedded sediments lack signs of reworking. The $\mathrm{CaH} 2$ section is composed of a succession of coarse-grained sand, fi ne-sand, and silty clay beds, the latter being sometimes rich in organic matter. Four lignite seams are interbedded in the fi nest deposits. Assuming that the bentonite level measured at $23 \mathrm{~m}$ in the $\mathrm{CaH} 1$ section is the same as that identified by Price et al. (1980; Fig. 3), $\mathrm{CaH} 1$ and $\mathrm{CaH} 2$ are respectively equivalent to section 2 and 6 of Parsons (2000). Moreover, bentonite levels were found in Ellesmere Island and were assumed to result from explosive volcanism during the opening of the Labrador Sea, Baffin Bay, and northern Atlantic (Reinhardt et al., 2013). Facies correspond to migrating channel belts, laterally associated with levee, crevasse splay, and swamp deposits, characteristic of a delta plain environment. A total of 35 and 22 samples were collected along the $\mathrm{CaH} 1$ and $\mathrm{CaH} 2$ sections, respectively. 


\section{METHODS}

Clay Mineralogy

Clay mineral $(<2 \mu \mathrm{m})$ associations were identified on all samples by X-ray diffraction (XRD) using a Bruker D2 phaser X-ray powder diffractometer equipped with a LynxEye detector (CuK $\alpha$ radiation, $\lambda=1.54 \AA$ and Ni filter). Oriented mounts were prepared for clay minerals analyses and three X-ray diagrams per sample were performed following the analytical procedure described in Holtzapffel (1985) and Moore and Reynolds (1997). Semiquantitative proportions of the identified minerals were obtained using the peak area of the basal reflection for each mineral, using MacDiff® 4.2.5 software. Some rock pieces were observed under Scanning Electron Microscopy to determine crystal morphology.

\section{U-Pb Isotopic Dating (ID-TIMS)}

Sample CASE15_YU067 (coordinates N 68 38219.53 / W 134 032 37.43, handheld GPS) from the $10 \mathrm{~cm}$ thick bentonite layer in section $\mathrm{CaH} 1$ was processed for $\mathrm{U}-\mathrm{Pb}$ zircon geochronology and measured (ID-TIMS) at the Boise State University Isotope Geology Laboratory, Idaho (USA). The results are shown in Table 1 and Figure 3. Heavy minerals were separated from $0.5 \mathrm{~kg}$ aliquots of volcanic tuff via progressive washing under ultrasonication following the method of Hoke et al. (2014), followed by conventional density and magnetic methods. Separate from each sample, the entire heavy mineral was placed in a muffle furnace at $900{ }^{\circ} \mathrm{C}$ for $60 \mathrm{~h}$ in quartz beakers to anneal minor radiation damage in zircon. Annealing enhances cathodoluminescence (CL) emission (Nasdala et al., 2002), promotes more reproducible interelement fractionation during laser ablation-inductively coupled plasma mass spectrometry (LA-ICPMS) (Allen and Campbell, 2012), and prepares the crystals for subsequent chemical abrasion (Mattinson, 2005). Following annealing, individual grains were handpicked for further isotopic analysis.

$\mathrm{U}-\mathrm{Pb}$ geochronology methods for isotope dilution thermal ionization mass spectrometry followed those previously published by Davydov et al. (2010) and Schmitz and Davydov (2012). Zircon crystals were subjected to a modified version of the chemical abrasion method of Mattinson (2005), whereby single crystal fragments plucked from grain mounts were individually abraded in a single step with concentrated $\mathrm{HF}$ at $180{ }^{\circ} \mathrm{C}$ for $12 \mathrm{~h}$. All analyses were undertaken on crystals previously mounted, polished, and imaged by cathodoluminence (CL), and selected on the basis of zoning patterns. U-Pb dates and uncertainties for each analysis were calculated using the algorithms of Schmitz and Schoene (2007) and the U decay constants of Jaffey et al. (1971). Uncertainties are based upon non-systematic analytical errors, including counting statistics, instrumental fractionation, tracer subtraction, and blank subtraction. These error estimates should be considered when comparing our ${ }^{206} \mathrm{~Pb} /{ }^{238} \mathrm{U}$ dates with those from other laboratories that used tracer solutions calibrated against the EARTHTIME gravimetric standards. When comparing our dates with those derived from other decay schemes (e.g., $\left.{ }^{40} \mathrm{Ar} /{ }^{39} \mathrm{Ar},{ }^{187} \mathrm{Re}^{187} \mathrm{Os}\right)$, the uncertainties in tracer calibration $(0.03 \%$; Condon et al., 2015; McLean et al., 2015) and U decay constants (0.108\%; Jaffey et al., 1971) should be added to the internal error in quadrature. Quoted errors for calculated weighted means are thus of the form $\mathrm{X}(\mathrm{Y})[\mathrm{Z}]$, where $\mathrm{X}$ is solely analytical uncertainty, $\mathrm{Y}$ is the combined analytical and tracer uncertainty, and $\mathrm{Z}$ is the combined analytical, tracer, and ${ }^{238} \mathrm{U}$ decay constant uncertainty.

\section{Rock-Eval Pyrolysis}

Rock-Eval pyrolysis was performed on all samples using a Rock-Eval 6 under standard conditions (Espitalié et al., 1985; Behar et al., 2001). The following parameters were determined: the Total Organic Carbon (TOC) content in weight $\%$, reflecting the quantity of pyrolysed carbon and residual organic carbon; the Hydrogen Index (HI) expressed in $\mathrm{mg}$ of hydrocarbons by gram of TOC; the Oxygen Index (OI) expressed in mg of carbon dioxide by 
gram of TOC, constraining kerogen types and their preservation state; and the Tmax expressed in ${ }^{\circ} \mathrm{C}$, used to estimate the degree of thermogenic maturation of the kerogen (Fig. 4).

\section{Palynofacies}

A total of 22 samples were selected for palynofacies observations, i.e., the identification of all particulate organic matter under the microscope in transmitted light (Tyson, 1995). Samples were crushed into millimetric pieces using a ceramic mortar, oven-dried, and treated with $\mathrm{HCl}$ and HF to remove the mineral matrix, and both total and sieved (fraction below 10 micron being removed) slides were prepared with the residues. The observations were carried out with an Axioplan2 Imaging Zeiss optical microscope under transmitted light and under UV excitation (Zeiss HBO 100 Microscope Illuminating System, mercury short-arc lamp). Over 1000 basic surface units per sample were counted to estimate the relative proportions of each organic group. The organic particles were grouped into the following categories: amorphous organic matter (AOM), phytoclast, and palynomorph groups. Based on shape, color, and fluorescence, the AOM can be subdivided into diffuse, granular, and gelified. The diffuse form is mainly yellow in natural light and exhibits fluffy shapes and weak to no fluorescence. The granular form is mainly gray to brown and exhibits irregular aggregated shapes and weak to no fluorescence. It sometimes contains small framboidal pyrite. The diffuse and granular AOM is thought to derive from phytoplankton, algae, and bacteria that accumulated in O2-depleted marine or lacustrine waters (Tyson, 1995), but may also derive from degraded terrestrial organic matter (Batten, 1996). The gelified AOM is orange to brown and lacks internal structures. As gelified AOM is here likely to correspond to degraded gelified phytoclasts (Tyson, 1995), we will further refer to gelified phytoclasts plus gelified AOM as gelified OM.

Phytoclasts are plant-derived fragments, including cuticles, woody tissues, and charcoals. In this study the phytoclast group is separated into opaque particles, translucent ligno-cellulosic fragments, and gelified particles, some very dark in color that look like gelified semi-opaque particles.

\section{Palynology}

A total of 35 samples were analyzed specifically for palynology. Pollen slide preparation followed a standard gentle method resulting in no damage to palynomorph membranes (Cour, 1974). Samples (15-25 g dry weight) were treated with $\mathrm{HCl}(35 \%)$ and $\mathrm{HF}$ (70\%) to remove carbonates and silicates. Denser particles were separated from the organic residue using $\mathrm{ZnCl} 2$ (density $=2.0$ ). Residues were filtered through a $150 \mu \mathrm{m}$ nylon sieve to eliminate the coarser particles, including organic macroremains. Palynomorphs were further concentrated using a 10 $\mu \mathrm{m}$ nylon sieve. The final residue was then homogenized and mounted onto microscope slides with glycerol. A transmitted light microscope was used for counting (at magnification $\times 200$ ) and identification (at magnification $\times 1000$ ) of palynomorphs. Pollen grains are particularly well preserved, a condition that allows a detailed examination of their morphological characters and their identification at the botanical family or genus level supported by comparison of the fossil specimens with those from databases of present-day species (collection of pollen slides, photographs, and iconographic atlases). Information on some critical pollen identifications is provided in the GSA Data Repository Item1. A minimum of 150 pollen grains were counted per sample in addition to those of Pinus. Detailed data are provided in Tables 2 and 3. Results are summarized in synthetic pollen diagrams presented in Figure 5B. Botanical identification of pollen grains allows the grouping of the recorded elements with respect to Nix's (1982) classification of living plants as reported in Tables 2 and 3: megatherm (tropical) elements (mean annual temperature $(\mathrm{MAT})>24{ }^{\circ} \mathrm{C}$ ); mega-mesotherm (subtropical) elements (20 ${ }^{\circ} \mathrm{C}<$ MAT $<24{ }^{\circ} \mathrm{C}$ ); Cathaya, a conifer living today in tropical-subtropical regions at mid- to high-elevations but below the Abies-Picea belt; mesotherm (warm-temperate) elements (14 
$\left.{ }^{\circ} \mathrm{C}<\mathrm{MAT}<20{ }^{\circ} \mathrm{C}\right)$; mesomicrotherm (cool-temperate) elements $\left(12{ }^{\circ} \mathrm{C}<\mathrm{MAT}<14{ }^{\circ} \mathrm{C}\right)$; and microtherm (boreal) elements (MAT $\left.<12{ }^{\circ} \mathrm{C}\right)$. The other elements are composed of: elements without climatic signification apart from some Cupressaceae (Juniperus-Cupressus-type), which occupy various biotopes (the pollen of which cannot be identified at the genus level); hygrophilous elements (i.e., water plants); and various herbs (Fig. 5B; Tables 2 and 3). A pollen ratio is calculated between "thermophilous" (megatherms + megamesotherms + mesotherms) and "non-thermophilous" (Cathaya and Podocarpus-type + meso-microtherms + microtherms) taxa, which is regarded as a representative index of temperature variation (Tables 2 and 3). Values of this ratio significantly $>1$ characterize warm periods (Popescu, 2002; Popescu et al., 2006).

\section{Carbon Isotope Analyses}

The organic carbon-isotope composition ( $\left.{ }^{\mathrm{T} M} 13 \mathrm{Corg}\right)$ was determined for 42 samples that were powdered using a grinder and decarbonated using $1 \mathrm{~N} \mathrm{HCl}$ for $2 \mathrm{~h}$ at $25{ }^{\circ} \mathrm{C}$ prior to analysis. Depending on the TOC contents, between 0.2 and $10 \mathrm{mg}$ of fully decarbonated sediment powder was weighted into tin capsules and placed in a PYRO cube ${ }^{\circledR}$ elemental analyzer connected to an Elementar Isoprime ${ }^{\circledR} 100$ isotope-ratio mass spectrometer in continuous flow. Each analytical run contained four sets of two standards (IAEA CH7, $\delta^{13} \mathrm{C}=-32.15 \%$; Caseine, $\delta^{13} \mathrm{C}=-27.18 \%$ ) to monitor analytical precision and accuracy. The carbon isotope results are reported relative to the "Vienna PeeDee belemnite" (VPDB) in delta notation. The precision, based on replicate analysis of standard and samples, was better than $0.13 \%$.

\section{Paleoclimatic Reconstruction Based on Palynology}

The climate has been reconstructed, thanks to palynology, for the Caribou Hills deposits using the "Climatic Amplitude Method" in which the climatic requirements of the maximum number of modern taxa are transposed to the fossil data (Fauquette et al., 1998a, 1998b). This approach relies on the relationship between the relative pollen abundance of each individual taxon and climate. It takes into account not only presence/absence criterion but also pollen percentages to provide more reliable reconstructions.

The estimated mean annual temperatures (MAT), coldest month mean temperature (CMMT), warmest month mean temperature (WMMT), mean annual precipitation (MAP), and available moisture concern the low-altitude vegetation because meso-microthermic and microthermic taxa have been excluded from the process to avoid a cold bias linked to transport from higher elevations. The excluded taxa are defined on the basis of their occurrence in modern vegetation zones (Walter, 1984), as vegetation types described for studied time period are found today in southeastern China from around $25-30^{\circ} \mathrm{N}$ and $110-120^{\circ} \mathrm{E}$ (Hou, 1983). In this region of China, the vertical distribution of the vegetation is characterized from the base to the top of the massifs (Taibai Shan in the Tsinling Massif, Shaanxi, Taba Shan, eastern Sichuan, or Hua Ping, Guangxi), by the evergreen broad-leaved forest, mixed evergreen and deciduous (Betula, Acer) broad-leaved forest, Cathaya/Tsuga forest, PicealAbies forest, and high mountain meadows (Wang, 1961; Hou, 1983). This modern distribution allows us to exclude the modern highaltitude taxa from the climatic reconstruction to obtain the low to middle-low altitude climate. The most probable climate for a fossil pollen assemblage is estimated as the climatic interval in which the highest number of taxa can exist and a "Most Likely Value" (MLV) corresponding to a weighted mean, according to the size of the climatic intervals of all taxa. As the precision of the information obtained from a taxon's climatic interval is inversely related to the breadth of this interval, the weights are greater for taxa with smaller intervals (for more details, see Fauquette et al., 1998a). 


\section{RESULTS}

\section{Clay Mineralogy}

The clay fraction $(<2 \mu \mathrm{m})$ mineralogy of samples of $\mathrm{CaH} 1$ and $\mathrm{CaH} 2$ sections is composed of kaolinite $(0-75 \%$, average value $30 \%)$, illite $(0-70 \%$, average value $30 \%)$, smectite $(0-100 \%$, average value $30 \%$ ), and chlorite (0-30\%, average value $15 \%$ ) (Fig. 5A).

Important differences in clay mineralogy are obvious between the two sections. Section $\mathrm{CaH} 1$ is characterized by high proportions of smectite $(10-100 \%$, mean value $50 \%$ ) when compared to $\mathrm{CaH} 2$, which is dominated by kaolinite (20-75\%, average value $45 \%$ ) (Fig. 5A). Illite is the second clay mineral represented in both sections and may correspond to the background physical erosion from the hinterland (Chamley, 1989). The illite crystallinity does not show continuous improvement along the sections, so no diagenetic overprint is highlighted. Chlorite is more abundant in $\mathrm{CaH} 2$ than in $\mathrm{CaH} 1$, a feature that may reflect local erosional inputs, as chloritic minerals are often thought to result from the physical erosion of catchment areas (Chamley, 1989). Kaolinite is generally poorly crystallized according to Scanning Electron Microscopy (SEM) observations. Only small to moderate amounts of well-crystallized crystals have been observed in some pure sand samples, showing that kaolinite has mainly detrital origins, and only localized, small amounts of kaolinite may be of diagenetic origin.

Kaolinite forms under intense hydrolyzing conditions and is considered to reflect warm and wet climatic conditions (Chamley, 1989; Velde and Meunier, 2008; Tramoy et al., 2016). Smectite forms under colder and/or dryer conditions, in poorly drained environments or under contrasted seasonality (Chamley, 1989; Tramoy et al., 2016).

The (Smectite + Kaolinite) / (Illite + Chlorite) ratio $(\mathrm{S}+\mathrm{K} / \mathrm{I}+\mathrm{C})$ may be used as a relative weathering indicator as smectite and kaolinite are secondary form clay minerals, whereas illite and chlorite are derived from physical erosion of parent rocks. The higher the ratio, the more elevated were the inland hydrolyzing conditions compared to physical erosion. The Smectite/Kaolinite ratio (S/K) may be used as a relative paleoclimatic proxy, with a high $\mathrm{S} / \mathrm{K}$ ratio indicating dryer and/or colder climate conditions. The $(\mathrm{S}+\mathrm{K} / \mathrm{I}+\mathrm{C})$ ratio is around 1 in most of the $\mathrm{CaH} 1$ section and decreases toward the top of the section. It varies from 1.5 to 3 in $\mathrm{CaH} 2$, and reaches high values between 20 and $30 \mathrm{~m}$ and around $40-45 \mathrm{~m}$ (Fig. 5A). The S/K ratio is high in the $\mathrm{CaH} 1$ section, mostly above 1 with three really high values (up to 4.9), whereas it is below 0.5 in most of the $\mathrm{CaH} 2$ section.

In $\mathrm{CaH} 1$, the kaolinite content is higher between 19-21 m and 24-26 m, when compared to the rest of the section. Conversely, smectite proportions are higher at the base and between 21 and $24 \mathrm{~m}$ when compared to the rest of the section. The bentonite level at the top of the section contains mostly smectite and traces of illite and kaolinite. In $\mathrm{CaH} 2$, the kaolinite content is higher than in $\mathrm{CaH} 1$ and decreases from the base of the section up to $21 \mathrm{~m}$, where the illite proportion is higher than the kaolinite proportion. From $21 \mathrm{~m}$ to $30 \mathrm{~m}$, the proportion of kaolinite increases and then decreases toward the top of the section (Fig. 5A).

\section{U-Pb Isotopic Dating (ID-TIMS)}

The heavy mineral separation of sample CASE15_YU067 resulted in an abundant population of sharply facetted, prismatic zircon crystals, with accompanying abundant prismatic apatite. Five grains were selected for CA-TIMS analysis on the basis of external morphology, clarity, and consistency. Chemical abrasion in concentrated $\mathrm{HF}$ at $190^{\circ}$ for $12 \mathrm{~h}$ resulted in only slight dissolution of the zircon crystals. Moderately high uranium concentration of these crystals resulted in modest radiogenic $\mathrm{Pb}$ contents and precisely measured isotope ratios.

All five crystals yielded concordant and equivalent isotope ratios, with a weighted mean ${ }^{206} \mathrm{~Pb} /{ }^{238} \mathrm{U}$ date of $54.304 \pm 0.029(0.039)[0.070] \mathrm{Ma}(\mathrm{MSWD}=1.18$; probability of fit $=0.317)$, which is interpreted as dating the eruption and deposition of this tuff. 


\section{Rock-Eval Pyrolysis}

The Rock Eval pyrolysis analyses indicate that TOC values vary from 0 to $56 \%$ and the HI values are below $350 \mathrm{mgHC} / \mathrm{gTOC}$. These values reveal a Type III (terrestrial derived) organic matter for most of the samples with minor marine influence for some samples (Fig. 5A). Tmax values are mainly below $435^{\circ} \mathrm{C}\left(359-438^{\circ} \mathrm{C}\right.$, with an average of $\left.411^{\circ} \mathrm{C}\right)$, indicative of immature kerogen. This Tmax variation range is not uncommon for outcrop samples and cannot be assigned to differences in maturity of the organic matter but is mostly due to weathering effect on the organic matter. The TOC values from the $\mathrm{CaH} 1$ section $(0$ $8.65 \%$, with an average of $2.36 \%)$ are lower than TOC values from $\mathrm{CaH} 2(0-51 \%$, with an average of $12 \%$ ), reflecting the occurrence of coal seams in $\mathrm{CaH} 2$. On average the $\mathrm{CaH} 2$ samples have higher HI values (26-322 $\mathrm{mgHC} / \mathrm{gTOC}$, with an average of $192 \mathrm{mgHC} / \mathrm{gTOC}$ ) compared to that of $\mathrm{CaH} 1$ (23-158 $\mathrm{mgHC} / \mathrm{gTOC}$, with an average of $60 \mathrm{mgHC} / \mathrm{gTOC}$ (Fig. $5 \mathrm{~B}$ ), suggesting that organic matter is probably better preserved in $\mathrm{CaH} 2$ than in $\mathrm{CaH} 1$. In $\mathrm{CaH} 2$, TOC values are higher between 25 and $50 \mathrm{~m}$ when compared to the rest of the section (Fig. 5A) due to the occurrence of lignite beds.

\section{Palynofacies}

Palynomorphs are observed in minor proportions and are dominated by bisaccate pollen grains. Spores are also present. Very few palynomorphs belonging to freshwater algae (Pediastrum) and dinoflagellate cysts have been observed. The development of Pediastrum algae is generally associated with an eutrophic freshwater environment (Tyson, 1995; Garel et al., 2013).

The samples from $\mathrm{CaH} 1$ are dominated by gelified organic matter, palynomorphs (i.e., pollen grains and/or spores and/or dinoflagellate cysts), and opaque phytoclasts, confirming a dominant terrestrial origin of the organic matter. Diffuse AOM also occurs in minor proportions. $\mathrm{CaH} 2$ samples also contain a large amount of gelified organic matter, which, together with phytoclasts, opaque phytoclasts, and palynomorphs, again indicates a terrestrial origin of the organic matter. Moreover, lower proportions of opaque phytoclasts and palynomorphs are recorded when compared to the $\mathrm{CaH} 1$ section. Finally, $\mathrm{CaH} 2$ samples contain a larger amount of translucent phytoclasts (Fig. 5B).

At the base of the $\mathrm{CaH} 1$ section, palynofacies are dominated by granular AOM associated with sandy deposits and also characterized by lower TOC values. In contrast, the top of the section is rich in gelified OM correlated to higher TOC values. It also contains important palynomorph proportions. At the base of $\mathrm{CaH} 2$, granular AOM dominates the palynofacies in sandy deposits with low TOC. The rest of the section is dominated by gelified OM, phytoclasts associated with higher TOC (Fig. 5B) corresponding to well-preserved OM from lignite formed in swamps.

\section{Pollen Grains and Dinoflagellate Cysts}

The pollen flora of $\mathrm{CaH} 1$ includes 69 taxa that have been grouped in a synthetic diagram (Fig. 5B) according to the mean annual temperature (MAT) range of their present-day relatives (Nix, 1982). Mega-mesotherm plants and Cupressaceae are dominant. Mesotherm plants, mesomicrotherm plants, and microtherm plants were also recorded but in comparatively lower proportions. Several specimens of the dinoflagellate cyst Apectodinium spp. have been recorded at the top of the section $(24.8 \mathrm{~m})$. The proportion of Pinus is very low along the section and decreases to the top with the exception of one sample at $19.5 \mathrm{~m}$. The "thermophilous/nonthermophilous taxa" ratio, continuously $>1$, increases toward the top of the section (Table 2). The pollen flora of $\mathrm{CaH} 2$ yielded 102 taxa and is also dominated by mega-mesotherm plants. In contrast with CaH1, megatherm plants including Avicennia (Fig. 6A-6D; Data Repository Plate DR4) and mesotherm plants are abundant (Fig. 5B). Pollen grains of microtherm plants are rare but with larger percentage than in $\mathrm{CaH} 1$. At the top of the section (near 41 and $50 \mathrm{~m}$ ) a large number of individual Azolla microspores, a freshwater fern, have been recorded. The 
proportion of Pinus is higher than in $\mathrm{CaH} 1$ and the thermophilous/non-thermophilous taxa ratio, still $>1$, shows very high values in the uppermost part of the section (Table 3).

\section{Carbon Isotopes}

The $\delta^{13}$ Corg values measured in $\mathrm{CaH} 1$ and $\mathrm{CaH} 2$ range from -27.7 to $-23.4 \%$ (Fig. 5B). The average $\delta^{13} \mathrm{Corg}$ values for $\mathrm{CaH} 1$ are $-26.1 \%$ and $-25.6 \%$ o for $\mathrm{CaH} 2$. These values are similar to those of modern $\mathrm{C} 3$ plants and to other $\delta^{13} \mathrm{Corg}$ values recorded for Paleocene-Eocene terrestrial organic matter around the world (Magioncalda et al., 2004; Jaramillo et al., 2010; Garel et al. 2013). In CaH1 the values fluctuate around $-26 \%$, with one sample at $20.95 \mathrm{~m}$ recording a value of $-27.7 \%$ and two samples at 23 and $24 \mathrm{~m}$ showing slightly higher values of $-25 \%$. In $\mathrm{CaH} 2, \delta^{13} \mathrm{Corg}$ values show an increase from the base to $30 \mathrm{~m}$, interrupted by three excursions to lower values $(<-26 \%$ ) at $0.2,3.2$, and $40.35 \mathrm{~m}$. One sample near $8 \mathrm{~m}$ has a distinctly higher value of $-23.4 \%$.

\section{Palaeoclimate Quantification Based on Palynology}

The climatic quantification based on the pollen flora of the $\mathrm{CaH} 1$ section shows high temperatures (MAT, CMMT, WMMT) and high precipitation at sea level for this part of the globe. Mean annual temperatures are between 16 and $25^{\circ} \mathrm{C}$, with "Most Likely Values" (MLV) between 18.2 and $19.3{ }^{\circ} \mathrm{C}$, CMMT between 5 and $15.5^{\circ} \mathrm{C}$ with MLV between 5.6 and $12{ }^{\circ} \mathrm{C}$, and WMMT between 25 and $28{ }^{\circ} \mathrm{C}$ with MLV between 25.8 and $26.4{ }^{\circ} \mathrm{C}$ along the section. Mean annual precipitation and available moisture are continuously high, at $1100-1600 \mathrm{~mm}$ (with MLV of 1160-1400 mm) and 66-100\% (with MLV of 77-87\%) (Fig. 5B), respectively. The quantification based on the pollen flora of the $\mathrm{CaH} 2$ section shows, from the base of the section to $41.2 \mathrm{~m}$, higher temperatures compared to CaH1, especially for CMMT (Fig. 5B). Mean annual precipitation estimates are similar in the two sections (Fig. 5B). From the base to 41.2 m, MAT are between 16 and $25^{\circ} \mathrm{C}$ with MLV between 21.3 and $22^{\circ} \mathrm{C}$ (except 2 levels at 18.5 and $19{ }^{\circ} \mathrm{C}$; Fig. 5B), CMMT between 10 and $15.5{ }^{\circ} \mathrm{C}$ with MLV of $10.5-14{ }^{\circ} \mathrm{C}$, and WMMT between 25 and $30{ }^{\circ} \mathrm{C}$ with MLV of $26.2-27.7^{\circ} \mathrm{C}$ along the section. MLV of MAP and available moisture are between $1200 \mathrm{~mm}$ and $1360 \mathrm{~mm}$ and between $75 \%$ and $92 \%$, respectively. From $41.5 \mathrm{~m}$ to the top, with the exception of 2 points showing higher temperatures, MAT are between 15 and $25^{\circ} \mathrm{C}$ with MLV of $17.8-19.7^{\circ} \mathrm{C}$, CMMT between 5 and $15.5^{\circ} \mathrm{C}$ with MLV between 7.6 and $11.6^{\circ} \mathrm{C}$, and WMMT between 25 and $28^{\circ} \mathrm{C}$ with MLV between 25.8 and $26.3{ }^{\circ} \mathrm{C}$. Most Likely Values of MAP and available moisture are between 1160 and $1400 \mathrm{~mm}$ and between $81 \%$ and $92 \%$, respectively.

\section{DISCUSSION}

\section{Age of the Sections}

\section{Caribou Hills 1 (CaH1)}

Parsons (2000), in his section 2, equivalent to $\mathrm{CaH} 1$, reported a foraminifer taxon (Portatrocharnmina tagluensis), which is characteristic of the Taglu sequence and is indicative of an early to middle Eocene age on the basis of associated dinoflagellate cysts and a rich assemblage of pollen grains and spores as defined by McNeil (1997) on his regional biostratigraphic chart. Thus, based on equivalence with section 2 in Parsons (2000), CaH1 probably corresponds to the lowest part of the Taglu sequence or the upper part of the Aklak sequence and is here considered as early Eocene in age. In our samples, Aquilapollenites pollen grains have been found in the $\mathrm{CaH} 1$ succession and could also indicate an early Eocene age (Harrison et al., 1999). This supposition is supported by the bentonite level U-Pb age of 54.304 Ma for the top of the CaH1 section (Figs. 3, 5A, and 5B; Table 1). According to Westerhold et 
al. (2017), the onset of the PETM and the ETM-2 hyperthermals have astronomically calibrated ages of 55.930 Ma and 54.050 Ma, respectively. Therefore, the bentonite layer on top of section CaH1 was deposited just before the onset of the ETM-2 hyperthermal.

The top of the CaH1 section yielded dinoflagellate cysts of the genus Apectodinium spp. Sporadic occurrences of Apectodinium were also recorded in the partly equivalent section 2 of Parsons and Norris (1999). The global Apectodinium acme coinciding with the negative carbon isotope excursions (Crouch et al., 2003; Sluijs et al., 2006) is a secondary marker of the PETM (Aubry et al., 2007). The occurrence of the species Apectodinium augustum, which is restricted to the CIE interval, is furthermore a useful criterion for identification of the PETM (Aubry et al., 2007; Sluijs et al., 2008). However, in accordance with McNeil and Parsons (2013), we did not find Apectodinium augustum in the Caribou Hills sections that we studied and the few Apectodinium spp. occurrences found do not account for an acme. In a section located stratigraphically $100 \mathrm{~m}$ below CaH1, Ioannides and McIntyre (1980) reported Apectodinium parvum, which may co-occur with Apectodinium augustum in Beaufort-Mackenzie wells but ranges considerably higher in the early Eocene (Damassa et al., 1990; McNeil and Parsons, 2013).

The carbon isotope measurements performed on both $\mathrm{CaH} 1$ and $\mathrm{CaH} 2$ sections can be used to refine this age assignation, if the obtained values are not biased by changing organic matter source or abundance. In both sections, neither linear nor logarithmic correlation is seen between

$\delta^{13}$ Corg and TOC, suggesting that carbon isotope values are not influenced by the amount of remaining organic carbon. To be sure that the correlation coefficients are significant, the autocorrelation of each proxy (clay minerals, organic matter parameters, and carbon isotopes) was tested with the R software (R Core Team, 2013), and shows no autocorrelation in the data (acf function, critic value $<0.2$ ). This lack of correlation suggests that the recorded changes in $\delta^{13}$ Corg values are mostly not attributable to changing organic sources or different stages of organic matter degradation, except for the coarser sand beds (e.g., CaH1 at $20.95 \mathrm{~m}$ ), where very low $\delta^{13}$ Corg values possibly reflect enrichment of lignin or other more resistant ${ }^{13} \mathrm{C}$ depleted components (Benner et al., 1987; Wynn et al., 2005; Foreman et al., 2013). The $\delta^{13} \mathrm{Corg}$ values at $\mathrm{CaH} 1$ are slightly lower than those recorded at $\mathrm{CaH} 2$, which could be associated with the interval showing lower $\delta^{13} \mathrm{C}$ values in lower Eocene marine carbonate materials (Vandenberghe et al., 2012). This association is supported by the warming trend recorded by clay mineralogy and pollen assemblages at $\mathrm{CaH} 1$ toward the top of the section with a slight increase in kaolinite highlighted by several kaolinite peaks, an increase of megamesotherm plant proportions, and an increase in the thermophilous/non-thermophilous taxa ratio. Given the above age constraints, we associate this record with the overall warming trend associated with the Early Eocene Thermal Optimum and proximity to the Eocene Thermal Maximum-2 (ETM-2) hyperthermal (Fig. 7).

\section{Caribou Hills 2 (CaH2)}

In the $\mathrm{CaH} 2$ section, pollen grains of megatherm plants are abundant, especially the mangrove element Avicennia (Fig. 5B), and thermophilous plants display a high diversity indicative of well-developed forest ecosystems and stable climatic warm conditions. Modern representatives of Avicennia are pollinated by animals and, thus, its pollen is expected to be present in very low quantity in coastal sediments, as suggested by analysis of modern coastal sediments offshore Ivory Coast and Thailand (Caratini et al., 1987; Somboon, 1990). A depleted mangrove with Avicennia showing pollen percentages similar to those observed in the $\mathrm{CaH} 2$ section are recorded in early mid-Miocene coastal marine sediments controlled by river input from the Northwestern Mediterranean region (Bessedik and Cabrera, 1985; Jiménez-Moreno and Suc, 2007). The Miocene context for pollen transport resembles that of the studied Caribou Hills sections: the active pollen transport by a river may explain the relatively high percentages of 
Avicennia (Table 3). In present-day surface sediments offshore Indonesia, the percentage of Avicennia pollen varies with distance from shoreline, and percentages matching with those of Caribou Hills must be interpreted as indicating a nearby mangrove (Engelhart et al., 2007). Moreover, microspores of the freefloating freshwater fern Azolla (Collinson, 2002) are abundant at the top of the section. A massive Azolla bloom is recorded in the central Arctic Ocean and in all Nordic Seas in strata of latest early Eocene age (49 Ma; van der Burgh et al., 2013; chron 22n-21r; Barke et al., 2012), interpreted as reflecting a massive freshwater discharge into the Arctic Ocean (Brinkhuis et al., 2006; Collinson et al., 2009; Greenwood et al., 2010; Barke et al., 2012) due to elevated precipitations in adjacent drainage areas. The duration of this Azolla bloom is estimated to have been $\sim 800 \mathrm{ky}$ (Brinkhuis et al., 2006) or 1.2 My (Barke et al., 2012). These comparisons suggest that the $\mathrm{CaH} 2$ sediments were deposited during the termination of the Early Eocene Climate Optimum and more precisely just before and at the onset of the Azolla event (49 Ma), in agreement with the late early to early middle Eocene age suggested by Parsons (2000) for his section 6, which is partly equivalent to $\mathrm{CaH} 2$ (Fig. 2).

These dating propositions are also supported by $\delta^{13} \mathrm{Corg}$ data from $\mathrm{CaH} 2$, which, similarly to $\mathrm{CaH} 1$, show no correlation with TOC, HI, or the type of organic particles described in the palynofacies section. The high frequency, small amplitude changes in $\delta^{13} \mathrm{Corg}$ values recorded at $\mathrm{CaH} 2$ could, however, reflect differences in the composition of the organic matter or even annual change in temperature and humidity, which are known to influence $\delta^{13} \mathrm{Corg}$ values of modern C3 plants (Jahren, 2007). In this regard, it is noteworthy that the negative $\delta^{13} \mathrm{Corg}$ excursion recorded between 37 and $40 \mathrm{~m}$ coincides with a marked increase in the proportion of pollen grains belonging to megatherm plants (Fig. 5B). As several studies have shown that higher precipitation decreases the $\delta^{13} \mathrm{C}$ values of C3 plants (Stewart et al., 1995; Diefendorf et al., 2010; Kohn, 2010; Schubert et al., 2012), this excursion could be attributed to a transient period of higher precipitation. Nevertheless, significant changes in mean annual precipitation are not supported by our climatic reconstruction or in similar studies for the same interval (Eldrett et al., 2009, 2014) or for the middle to late Paleocene in the Northwest Territories (Greenwood et al., 2010). Notwithstanding this excursion, the $\mathrm{CaH} 2$ succession shows average $\delta^{13}$ Corg values that are significantly higher than in $\mathrm{CaH} 1$, and may thus correlate with marine strata showing higher values toward the termination of the EECO (Fig. 7). Altogether, these palynological and geochemical data support a late early Eocene age for the $\mathrm{CaH} 2$ section.

\section{Reconstruction of Depositional Environments}

The high amounts of smectite, the absence of illite-smectite mixed layers, the stratigraphically invariant illite crystallinity, and the low average Tmax values $\left(<435^{\circ} \mathrm{C}\right)$ recorded in the two studied sections indicate limited burial and thermal overprinting and allow the interpretation of organic matter and clay assemblages in terms of paleoenvironmental conditions.

The pseudo Van Krevelen diagram (Fig. 4) and the palynofacies suggest that the organic matter of the two sections mostly corresponds to terrestrial higher plants debris. The numerous plant cell structures observed in the palynofacies suggest a rather well-preserved organic matter and the relative proximity of terrestrial organic sources. Few dinoflagellate cysts have been observed along the sections (stars on Fig. 5B), indicating some marine incursions and relative proximity of the coastline. In $\mathrm{CaH} 1$, dinoflagellate cysts are found at $0.65,18,20.5,21.4,22.4$, 23.4, and $24.8 \mathrm{~m}$. In $\mathrm{CaH} 2$, only three samples exhibit very few dinoflagellate cysts, at 3.7, 7.6, and $51.2 \mathrm{~m}$, and thus indicate a more proximal environment compared to $\mathrm{CaH} 1$. This is in agreement with the higher proportions of small equant opaque phytoclasts $(50 \mu \mathrm{m})$ and pollen grains in the palynofacies assemblages of $\mathrm{CaH} 1$ when compared to those of $\mathrm{CaH} 2$. Small equantopaque phytoclasts particles have a high buoyancy (McArthur et al., 2016) and thus suggest a longer aquatic transport for organic particles at $\mathrm{CaH} 1$ when compared to $\mathrm{CaH} 2$. 
The pollen assemblage of $\mathrm{CaH} 1$ is characteristic of littoral forests with freshwater to marine water swamp trees (Glyptostrobus-Taxodium-type) and fern (Osmunda). Freshwater marshes were also present as illustrated by Myrica, Cyperaceae, and the association of Cuphea, Menyanthaceae, Myriophyllum, Oenotheraceae, Restionaceae, and Typha. Very few specimens of brackish marshes species are found, such as many Amaranthaceae species and Tamarix. The hinterland was probably covered by evergreen broadleaf forests (Engelhardia, Amanoa, Distylium, Cupressaceae, Sapotaceae) and with increasing altitude by deciduous broadleaf mesophilous forests (Alnus, Carpinus, Carya, Liquidambar, Populus, Pterocarya, Quercus, Ulmus, Zelkova), both growing in a humid climate. Proximity of a higher elevation massif is indicated by Cathaya, Podocarpus-type, Cedrus, Tsuga, Abies, and Picea. The CaH1 section is characterized by massive silty clay sediments without root traces. Such fine-grained deposits more or less enriched in organic matter are indicative of low-energy conditions that we attribute to outer levees or swamps of deltaic plains. The centimeter-thick laminated sand located at 20 $\mathrm{m}$ could correspond to a crevasse splay deposit. In summary, the CaH1 succession corresponds to a proximal, dominantly freshwater littoral swamp environment with intermittent connections with marine areas.

Pollen assemblage of $\mathrm{CaH} 2$ suggests a freshwater to marine water swamp forest (Glyptostrobus-Taxodium-type), but in a warmer climatic context as illustrated by the presence of megatherm elements (Amanoa, Bombax, Buxus bahamensis-type, Croton, Fabaceae Mimosoideae, Icacinaceae, Resedaceae, and Theaceae). The occurrence of Avicennia pollen on $\mathrm{CaH} 2$ is indicative of a mangrove swamp environment, and confirms the presence of this genus in the Eocene Arctic as initially suggested by pollen data of coastal plain sediments from the New Siberia Islands (Suan et al., 2017).

Mangrove is a salt tolerant forest environment containing diverse assemblages of trees and shrubs and developing along sheltered tropical to subtropical coasts (Mao et al., 2012), where the average annual temperature of seawater is at or above $18{ }^{\circ} \mathrm{C}$ (Chapman, 1976). Avicennia is the mangrove genus that can support relatively cooler temperatures compared to other mangrove taxa and may extend into marginally subtropical areas in the Southern Hemisphere (Duke et al., 1998; Quisthoudt et al., 2012). Modern Avicennia mangrove forest develops on soft, exposed mudflats of low to middle intertidal zones inundated by high tides, although they may occasionally develop in the high intertidal zone (Duke et al., 1992). This taxon indicates a mangrove environment inundated by high tides, as recorded in modern coastal areas of Southeast Asia (Giesen et al., 2007). A depleted mangrove with Nypa probably out of its typical latitudinal climate zone was already evidenced at the same time period in Tasmania at a similar paleolatitude (Pole and Macphail, 1996; Carpenter et al., 2012). This mangrove swamp would have been located near a fluvial channel belt, as suggested by the occurrence of unconsolidated sand and gravel deposits surrounded by fine sand, silty clay, and coal deposits. These fining upward sequences are characteristic of channel, levee, and backswamp deposits. At the base of the $\mathrm{CaH} 2$ section, a sand layer shows parallel laminations and as suggested for a bed of similar aspect at $\mathrm{CaH} 1$, is here interpreted as crevasse splay deposit.

As for $\mathrm{CaH} 1$, the pollen data of $\mathrm{CaH} 2$ indicate that the hinterland forest environments contained evergreen broadleaf megathermic and mega-mesothermic taxa (Amanoa, Sapotaceae, Engelhardia, Distylium) and mesophilous taxa (Alnus, Carpinus, Carya, Liquidambar, Populus, Pterocarya, Quercus, Ulmus, Zelkova). Pollen grains of deciduous plants and mesomicrotherm and microtherm taxa are more abundant in $\mathrm{CaH} 2$ than in $\mathrm{CaH} 1$, which appears surprising given that the $\mathrm{CaH} 2$ section also yielded numerous and diversified pollen grains of megatherm and mega-mesotherm elements (Fig. 6B). The higher abundance of these elements could be explained by an uplift phase of the neighboring hinterland heights; this uplift would have either decreased the distance between the main areas of these plants and the studied coastal deposits, or increased the areas favorable to their development. This hypothesis is also 
supported by higher amounts of chlorite minerals in $\mathrm{CaH} 2$, which could be related to an erosion pulse of hinterland areas. Alternatively, the higher abundance of meso-microtherm and microtherm plants in $\mathrm{CaH} 2$ could reflect a shift in the fluvial network draining higher altitudinal source areas. Source areas for Beaufort-Mackenzie Basin sediments from the Eocene consisted of the northern Cordillera, including the Ogilvie and Richardson Mountains, the Porcupine River drainage basin, and the northeastern Brooks Range (Duk-Rodkin and Hughes, 1994). During the Paleocene and Eocene these mountains underwent major uplift due to the accretion of terranes along the west margin of North America. In summary, the $\mathrm{CaH} 2$ succession was in a proximal, freshwater swamp and mangrove environment with a more limited connection to the open sea that could be inundated only during high tides.

\section{Paleoclimatic Conditions}

Clay assemblages from the $\mathrm{CaH} 1$ section are dominated by smectite, suggesting drier and/or colder and/or seasonally contrasted climate (Chamley, 1989) when compared to $\mathrm{CaH} 2$. CaH1 shows kaolinite proportions mostly around $10 \%$, indicating colder and/or dryer paleoclimate compared to the high kaolinite proportions (40\% in average) recorded in $\mathrm{CaH} 2$. This is in agreement with the lower proportions of megatherm and megamesotherm plants in $\mathrm{CaH} 1$ and the climate estimates that indicate lower temperatures for $\mathrm{CaH} 1$ than $\mathrm{CaH} 2$ (Fig. 6b). Conversely, a warm and humid paleoclimate is suggested by the higher kaolinite content in $\mathrm{CaH} 2$, in agreement with high values of the $\mathrm{S}+\mathrm{K} / \mathrm{I}+\mathrm{C}$ ratio, low values of $\mathrm{S} / \mathrm{K}$, high pollen proportions of megatherm and mega-mesotherm plants (Amanoa, Bombax, Buxus bahamensistype), and high temperature estimates, especially from the base to $41.2 \mathrm{~m}$. Furthermore, at $\mathrm{CaH} 2$, the Most Likely Values of MAT (between 21.3 and $22^{\circ} \mathrm{C}$ ) and MAP (between 1200 and $1360 \mathrm{~mm}$ ) are compatible with kaolinite formation in soils. In both sections, illite and chlorite are present in high proportions, reflecting a high detrital input and active erosion of the hinterland, consistent with the record of pollen of meso-microtherm and microtherm plants that were most likely sourced from hinterland heights.

The two sections also record short-term variations in temperature or precipitation. In $\mathrm{CaH} 1$, as stated previously, the higher proportion of kaolinite toward the top of the section is associated with a lower $\mathrm{S}+\mathrm{K} / \mathrm{I}+\mathrm{C}$ ratio that could reflect higher physical erosion due to higher precipitation. The higher proportion of mega-mesotherm plants, thermophilous taxa to the top of the section also attest for a warming trend from the base to top of $\mathrm{CaH} 1$ section.

In $\mathrm{CaH} 2$, the proportion of pollen grains of megatherm plants decreases toward the top of the section above $42 \mathrm{~m}$ in association with higher proportions of mesotherm and microtherm plants. Above $41.5 \mathrm{~m}$, temperatures become lower than during the first part of the sequence, especially for the coldest month mean temperature, equivalent to $\mathrm{CaH} 1$ temperatures (Fig. 5B). This interval shows lower kaolinite proportions and $\mathrm{S}+\mathrm{K} / \mathrm{I}+\mathrm{C}$ ratios lower than 1 . This interval could therefore be linked to the onset of the cooling phase following the EECO starting near $50 \mathrm{Ma}$ (Fig. 7). Later in this region, SST rose from 10 to $13{ }^{\circ} \mathrm{C}$ at the termination of the Azolla event. Along $\mathrm{CaH} 2$, high $\mathrm{S}+\mathrm{K} / \mathrm{I}+\mathrm{C}$ and $\mathrm{S} / \mathrm{K}$ ratios at $3.2,27$, and $40.75 \mathrm{~m}$ indicate an increase in smectite contents and thus likely point to transient intervals of cooler or dryer climate conditions, in line with the drop in abundance of megatherm taxa in corresponding strata and with the occurrence of Azolla at $40 \mathrm{~m}$. As Azolla is thought to indicate higher precipitation (Brinkhuis et al. 2006), the increase in smectite at $40 \mathrm{~m}$ likely reflects a cooler climate. However, Avicennia is still present, and climatic estimates do not show changes.

The record of warm and wet climate conditions in the Mackenzie Delta of the Eocene Arctic is consistent with other studies of coeval strata in Ellesmere Island, Axel Heiberg Island, Greenland, Norwegian Sea, and New Siberian Islands (Table 4; Fig. 1), where both macro and micro remains of humid temperate swamp forests and lush rain forests have been also reported 
(Kalkreuth et al., 1998; Eldrett et al., 2009, 2014; Eberle et al., 2010; Greenwood et al., 2010; Harrington et al., 2011; West et al., 2015; Suan et al., 2017). Mild warm-temperate climates with mean annual temperatures (MAT) around $8-15{ }^{\circ} \mathrm{C}$ have been estimated for the early and middle Eocene around the Arctic. Warm and wet summers prevailing in the Arctic during the early and early middle Eocene, with the WMMT between 18 and $26^{\circ} \mathrm{C}$ and MAP values around $1200 \mathrm{~mm}$, and mild winters (CMMT between 0 and $13{ }^{\circ} \mathrm{C}$; Basinger et al., 1994; Greenwood and Wing, 1995; Brinkhuis et al., 2006; Sluijs et al., 2009; Greenwood et al., 2010; Eberle et al., 2010, 2014; Suan et al., 2017) enabled the growth of a forest assemblage of deciduous and evergreen conifers. Such MAT and humidity conditions are presently found in regions such as southeast North America or southeast China, which have plant associations similar to those recorded in Eocene Arctic forests (Kumagai et al., 1995). Warm climates during the early and latest early Eocene are recorded in many localities around the world, for example in Wyoming, Texas, Canada, England, and high latitude Antarctica (Robert and Kennett, 1994; Andreasson and Schmitz, 1996; Wilf, 2000; Pross et al., 2012; Smith et al., 2012; Jacques et al., 2014; Gushulak et al., 2016), with temperatures up to $10-30{ }^{\circ} \mathrm{C}$ higher when compared to those characterizing modern high- and midlatitude areas. These warm temperatures are associated either with high precipitation, especially in high- and mid-latitudes (Robert and Kennett, 1992; Wilf, 2000) or monsoon-like climates at lower latitudes (Shukla et al., 2014; Bougeois et al., 2014; West et al., 2015; Gushulak et al., 2016; Spicer et al., 2016). All these records provide strong evidence for a reduced latitudinal temperature gradient during the Eocene (Zachos et al., 1994; Andreasson and Schmitz, 2000; Sluijs et al., 2006) and tend to invalidate recent hypotheses postulating that the Eocene high-latitude warmth is an artifact of paleothermometer miscalibrations or oxygen isotope diagenetic overprint (Ho and Laepple, 2016; Bernard et al., 2017).

Our results thus provide further evidence for climate conditions that are exceptionally warmer and more humid than today in the high latitude regions of the northern hemisphere during the early Eocene, and, in this regard, can be used as critical climatic constraints for future climate modeling work, similarly to the modelling works by Huber and Caballero (2011) and Huber and Goldner (2012), which used climate condition reconstructions determined from studies on sections. Furthermore, we note that pollen grains of Avicennia are, for the first time, recognized in the Canadian margin of the Arctic Basin. This strengthens the idea that the exceptional Arctic warmth of the Eocene was a phenomenon characterizing both coastal marine and atmospheric environments (Suan et al., 2017).

Beyond these climatic implications, the occurrence of Avicennia pollen in the Arctic Canada, through analogy with modern representatives of this genus that only spread through a marine transport of their propagules (Quisthoudt et al., 2012), implies a marine connection between the Arctic Basin and the mid-latitude oceans. Avicennia pollen is known today to be transported a very short distance $(<2 \mathrm{~km})$ from its source (Somboon, 1990; Behling et al., 2001), thus indicating the presence of this mangrove around the Arctic Ocean in the early Eocene. According to several authors (Ellison et al., 1999; Duke et al., 2002; Lo et al., 2014) the mangrove evolved around the Tethys Sea during the Late Cretaceous and spread over long distances through oceanic currents. The only gateways through which this dispersal may have occurred during this time interval were the Greenland- Norway Seaway connecting the Atlantic and Arctic oceans (Roberts et al., 2009; Fig. 1) and the Turgai Strait connecting the Tethys and Arctic Oceans (open at least until the Lutetian according to Iakovleva et al., 2001, and until the Oligocene according to Rögl, 1999). We can therefore assume that oceanic currents flowing toward the Arctic Ocean existed through at least one of these gateways at this time. Their influence on the mean salinity of the Arctic Ocean was, however, probably limited, as shown by the development of the Azolla freshwater fern. Moreover, the occurrence of Avicennia on both the Siberian and Canadian margins also implies the existence of oceanic currents within 
the Arctic Ocean during the Eocene. Although further data are needed to constrain its detailed patterns, such an oceanic circulation could have been similar to the modern Beaufort gyre and Transpolar drift, which has been previously suggested to have developed only after at $46 \mathrm{Ma}$ (Backman and Moran, 2009). The occurrence of Avicennia pollen grains on both sides of the Arctic, as highlighted by our new results, suggests that the onset of such a trans-Arctic oceanic circulation may have occurred as early as during the early Eocene.

\section{CONCLUSIONS}

This multiproxy study leads to several conclusions dealing with the climatic variations during the early Eocene in the Canadian margin of the Arctic Ocean:

- The two studied sections $(\mathrm{CaH} 1$ and $\mathrm{CaH} 2)$ of the Caribou Hills represent high-latitude records, near $75^{\circ} \mathrm{N}$, of early and late early Eocene ages, respectively. The new U-Pb zircon (IDTIMS) age of $54.304( \pm 0.029)$ Ma of the bentonite layer in section CaH1 proves deposition of the sediments just before the Early Eocene Thermal Maximum 2 hyperthermal. $\mathrm{CaH} 1$ and $\mathrm{CaH} 2$ sediments were deposited under a subtropical climate and warmer conditions during the late early Eocene, respectively, as shown by consistent mineralogical and palynological records. For the two sections, the paleoclimatic reconstruction indicates most likely values of MAT between 18 and $22{ }^{\circ} \mathrm{C}$, CMMT between 6 and $14{ }^{\circ} \mathrm{C}$, WMMT between 26 and $28{ }^{\circ} \mathrm{C}$, MAP between 1200 and $1400 \mathrm{~mm}$, and available moisture between 75 and 95\%, compatible with kaolinite formation in soils.

- The two portions of the Caribou Hills outcrop represent two delta plain environments with littoral forests including swamps in a hinterland landscape dominated by evergreen broadleaf forest and with increased altitude by deciduous forest.

- We report the first occurrence of Avicennia pollen in the Canadian Arctic, which indicates that mangrove environments developed along Canadian Arctic coastlines during the early Eocene. Such mangrove environments, recently recognized in Eocene deposits of the New Siberia Islands (Suan et al., 2017), imply that warm and wet conditions were widespread along the Arctic coast during the early Eocene. These Avicennia pollen records also imply that oceanic currents connected Siberian and Arctic Canadian margins as early as during the early Eocene.

\section{ACKNOWLEDGMENTS}

This study was funded by TOTAL through the project Groupement Recherche Industrie (GRI) zones péri-arctiques. We acknowledge Florence Savignac, François Fourel, Ingrid Antheaume, Omar Boudouma, and Vincent Grossi for their help with analytical procedures. We wish to thank two anonymous reviewers for their constructive remarks.

\section{REFERENCES}

Akhmetiev, M.A., and Beniamovski, V.N., 2009, Paleogene floral assemblages around epicontinental seas and straits in Northern Central Eurasia: proxies for climatic and paleogeographic evolution: Geologica Acta, v. 7, no. 1-2, p. 297-309.

Allen, C.M., and Campbell, I.H., 2012, Identification and elimination of a matrix-induced systematic error in LA-ICP-MS ${ }^{206} \mathrm{~Pb} /{ }^{238} \mathrm{U}$ dating of zircon: Chemical Geology, v. 332-333, p. 157-165, https://doi.org/10.1016/jchemgeo.2012.09.038.

Andreasson, F. P., and Schmitz, B., 1996, Winter and summer temperatures of the early middle Eocene of France from Turritella $\delta^{18} \mathrm{O}$ profiles: Geology, v. 24, p. 1067-1070, https://doi.org/10.1130/0091-7613. 024<1067:WASTOT>2.3.CO;2. 
Andreasson, F.P., and Schmitz, B., 2000, Temperature seasonality in the early middle Eocene North Atlantic region: Evidence from stable isotope profiles of marine gastropod shells: Geological Society of America Bulletin, v. 112, no. 4, p. 628-640, https://doi.org/10.1130/0016 7606(2000)112<628:TSITEM>2.0.CO;2.

Aubry, M.P., Berggren, W.A., Van Couvering, J.A., Ali, J., Brinkhuis, H., Cramer, B., Kent, D.V., Swisher, C.C., Dupuis, C., Gingerich, P.D., Heilmann-Clausen, C., King, C., Ward, D.J., Knox, R.W., Ouda, K., Stott, L.D., and Thiry, M., 2003, Chronostratigraphic terminology at the Paleocene/Eocene boundary, in Wing, S.L., Gingerich, P.D., Schmitz, B., Thomas, E, eds., Causes and consequences of globally warm climates in the early Paleogene: Geological Society of America Special Paper 369, p. 551-566, https://doi.org/10.1130/0-8137-2369-8.551.

Aubry, M.P., Ouda, K., Dupuis, C., Berggren, W.A., Van Couvering, J.A., Ali, J., and Ward, D.R., 2007, The Global Standard Stratotype-section and Point (GSSP) for the base of the Eocene Series in the Dababiya section (Egypt): Episodes, v. 30, no. 4, p. 271-286.

Backman, J., and Moran, K., 2009, Expanding the Cenozoic paleoceanographic record in the Central Arctic Ocean: IODP Expedition 302 Synthesis: Central European Journal of Geosciences, v. 1, no. 2, p. 157-175.

Barke, J., Abels, H.A., Sangiorgi, F., Greenwoof, D.R., Sweet, A.R., Donders, T., Reichart, G.-J., Lotter, A.F., and Brinkhuis, H., 2011, Orbitally forced Azolla blooms and Middle Eocene Arctic hydrology: clues from palynology: Geology, v. 39, no. 5, p. 427-430, https://doi.org/10.1130/G31640.1.

Barke, J., van der Burgh, J., van Konijnenburg-van Cittert, J.H., Collinson, M.E., Pearce, M.A., Bujak, J., Heilmann-Clausen, C., Speelman, E.N., van Kempen, M.M.L., Reichart, G.J., Lotter, A.F., and Brinkhuis, H., 2012, Coeval Eocene blooms of the freshwater fern Azolla in and around Arctic and Nordic seas: Palaeogeography, Palaeoclimatology, Palaeoecology, v. 337, p. 108-119, https://doi.org/10.1016/j.palaeo.2012.04.002.

Basinger, J.F., Greenwood, D.R., and Sweda, T., 1994, Early Tertiary vegetation of Arctic Canada and its relevance to paleoclimatic interpretation, in Boulter, M.C., and Fisher, H.C. eds., Cenozoic plants and climates of the Arctic: Springer Berlin Heidelberg, NATO ASI Series 27, p. $175-198$, https://doi.org/10.1007/978-3-642-79378-3_13.

Batten, D.J., 1996, Palynofacies and paleoenvironmental interpretation, in Jansonius, J., and McGregor, D.C. eds., Palynology: Principles and Applications: American Association of Stratigraphic Palynologists Foundation, p. 1011-1064.

Behar, F., Beaumont, V., and Penteado, H.D.B., 2001, Rock-Eval 6 technology: performances and developments: Oil \& Gas Science and Technology, v. 56, no. 2, p. 111-134, https://doi.org/10.2516/ogst:2001013.

Behling, H., Cohen, M.C.L., and Lara, R.J., 2001, Studies on Holocene mangrove ecosystem dynamics of the Bragança Peninsula in north-eastern Pará, Brazil: Palaeogeography, Palaeoclimatology, Palaeoecology, v. 167, no. 3-4, p. 225-242, https://doi.org/10.1016/S0031-0182(00)00239-X.

Benner, R., Fogel, M.L., Sprague, E.K., and Hodson, R.E., 1987, Depletion of $13 \mathrm{C}$ in lignin and its implications for stable carbon isotope studies: Nature, v. 329, no. 6141, p. 708, https://doi.org/10.1038/329708a0.

Bernard, S., Daval, D., Ackerer, P., Pont, S., and Meibom, A., 2017, Burialinduced oxygen-isotope reequilibration of fossil foraminifera explains ocean paleotemperature paradoxes: Nature Communications, v. 8, no. 1, p. 1134, https://doi.org/10.1038/s41467-017-01225-9.

Bessedik, M., and Cabrera, L., 1985, Le couple récif-mangrove à Sant Pau d'Ordal (Vallès-Pénédès, Espagne), témoin du maximum transgressif en Méditerranée nord occidentale (Burdigalien supérieur Langhien inférieur): Newsletters on Stratigraphy, v. 14, no. 1, p. 20-35, https://doi.org/10.1127/nos/14/1985/20.

Bougeois, L., De Rafélis, M., Reichart, G.J., De Nooijer, L.J., Nicollin, F., and Dupont-Nivet, G., 2014, A high resolution study of trace elements and stable isotopes in oyster shells to estimate Central Asian Middle Eocene seasonality: Chemical Geology, v. 363, p. 200-212, https://doi.org/10.1016/j.chemgeo.2013.10.037.

Brinkhuis, H., Schouten, S., Collinson, M.E., Sluijs, A., Damsté, J.S.S., Dickens, G.R., and Moran, K., 2006, Episodic fresh surface waters in the Eocene Arctic Ocean: Nature, v. 441, no. 7093, p. 606609, https://doi.org/10.1038/nature04692. 
Caratini, C., Tastet, J.-P., Tissot, C., and Frédoux, A., 1987, Sédimentation palynologique actuelle sur le plateau continental de Côte d'Ivoire: Mémoires et Travaux de l'Ecole Pratique des Hautes Etudes: Institut de Montpellier, v. 17, p. 69-100.

Carpenter, R.J., Jordan, G.J., Macphail, M.K., and Hill, R.S., 2012, Neartropical Early Eocene terrestrial temperatures at the Australo-Antarctic margin, western Tasmania: Geology, v. 40, no. 3, p. 267-270, https://doi.org/10.1130/G32584.1.

Chamley, H., 1989, Clay Sedimentology: Springer Science and Business Media, 623 p., https://doi.org/10.1007/978-3-642-85916-8.

Chapman, V.J., 1976, Mangrove Vegetation: Vaduz, J. Cramer, 447 p.

Collinson, M.E., 2002, The ecology of Cainozoic ferns: Review of Palaeobotany and Palynology, v. 119, no. 1, p. 51-68, https://doi.org/10.1016/S0034-6667(01)00129-4.

Collinson, M.E., Barke, J., van der Burgh, J., and van Konijnenburg-van Cittert, J.H., 2009, A new species of the freshwater fern Azolla (Azollaceae) from the Eocene Arctic Ocean: Review of Palaeobotany and Palynology, v. 155, no. 1, p. 1-14, https://doi.org/10.1016/j.revpalbo.2008.12.014.

Condon, D.J., Schoene, B., McLean, N.M., Bowring, S.A., and Parrish, R.R., 2015, Metrology and traceability of U-Pb isotope dilution geochronology (EARTHTIME Tracer Calibration Part I): Geochimica et Cosmochimica Acta, v. 164, p. 464-480, https://doi.org/10.1016/j.gca.2015.05.026.

Cour, P., 1974, Nouvelles techniques de détection des fl ux et retombées polliniques: Etude de la sédimentation des pollens et des spores à la surface des sols: Pollen et spores, v. 16, p. 103-141.

Crouch, E.M., Dickens, G.R., Brinkhuis, H., Aubry, M.P., Hollis, C.J., Rogers, K.M., and Visscher, H., 2003, The Apectodinium acme and terrestrial discharge during the Paleocene-Eocene thermal maximum: new palynological, geochemical and calcareous nannoplankton observations at Tawanui, New Zealand: Palaeogeography, Palaeoclimatology, Palaeoecology, v. 194, no. 4, p. 387-403, https://doi.org/10.1016/S0031-0182(03)00334-1.

Damassa, S.P., Goodman, D.K., Kidson, E.J., and Williams, G.L., 1990, Correlation of Paleogene dinoflagellate assemblages to standard nannofossil zonation in North Atlantic DSDP sites: Review of Palaeobotany and Palynology, v. 65, no. 1-4, p. 331-339, https://doi.org/10.1016/0034-6667(90)90083U.

Davydov, V.I., Crowley, J.L., Schmitz, M.D., and Poletaev, V.I., 2010, Highprecision U-Pb zircon age calibration of the global Carboniferous time scale and Milankovitch-band cyclicity in the Donets Basin, eastern Ukraine: Geochemistry Geophysics Geosystems, https://doi.org/10.1029/2009GC002736.

DeConto, R.M., Galeotti, S., Pagani, M., Tracy, D., Schaefer, K., Zhang, T., and Beerling, D.J., 2012, Past extreme warming events linked to massive carbon release from thawing permafrost: Nature, v. 484, p. 87-91, https://doi.org/10.1038/nature10929.

Diefendorf, A.F., Mueller, K.E., Wing, S.L., Koch, P.L., and Freeman, K.H., 2010, Global patterns in leaf $13 \mathrm{C}$ discrimination and implications for studies of past and future climate: Proceedings of the National Academy of Sciences of the United States of America, v. 107, p. 5738-5743, https://doi.org/10.1073/pnas.0910513107.

Dixon, J., 1986, Cretaceous to Pleistocene stratigraphy and paleogeography, northern Yukon and northwestern District of Mackenzie: Bulletin of Canadian Petroleum Geology, v. 34, no. 1, p. 49-70.

Dixon, J., 1992, A review of Cretaceous and Tertiary stratigraphy in the northern Yukon and adjacent Northwest Territories: Ottawa, Canada, Geological Survey of Canada, Paper 92-9, https://doi.org/10.4095/134182.

Dixon, J., 1996, Geological atlas of the Beaufort-Mackenzie area, Ottawa, Canada: Geological Survey of Canada Miscellaneous Report 59, 173 p.

Dixon, J., Dietrich, J.R., Lane, L.S., and McNeil, D.H., 2008, Geology of the Late Cretaceous to Cenozoic Beaufort-Mackenzie Basin, Canada: Sedimentary Basins of the World, v. 5, p. 551-572, https://doi.org/10.1016/S1874-5997(08)00016-6.

Duk-Rodkin, A., and Hughes, O.L., 1994, Tertiary-Quaternary drainage of the pre-glacial Mackenzie Basin: Quaternary International, v. 22, p. 221-241, https://doi.org/10.1016/1040-6182(94)90015-9.

Duke, N.C., Zuleika, S., and Pinzon, M., 1992, Aging Rhizophora seedlings from leaf scar nodes: a technique for studying recruitment and growth in mangrove forests: Biotropica, v. 24, p. 173-186, https://doi.org/10.2307/2388671. 
Duke, N.C., Benzie, J.A., Goodall, J.A., and Ballment, E.R., 1998, Genetic structure and evolution of species in the mangrove genus Avicennia (Avicenniaceae) in the Indo-West Pacific: International Journal of Organic Evolution, v. 52, p. 1612-1626, https://doi.org/10.1111/j.15585646.1998.tb02242.x.

Duke, N.C., Lo, E., and Sun, M., 2002, Global distribution and genetic discontinuities of mangrovesemerging patterns in the evolution of Rhizophora: Trees (Berlin), v. 16, no. 2-3, p. 65-79, https://doi.org/10.1007/s00468-001-0141-7.

Eberle, J.J., Fricke, H.C., Humphrey, J.D., Hackett, L., Newbrey, M.G., and Hutchison, J.H., 2010, Seasonal variability in Arctic temperatures during early Eocene time: Earth and Planetary Science Letters, v. 296, no. 3, p. 481-486, https://doi.org/10.1016/j.epsl.2010.06.005.

Eberle, J.J., and Greenwood, D.R., 2012, Life at the top of the greenhouse Eocene world-A review of the Eocene flora and vertebrate fauna from Canada's High Arctic: Geological Society of America Bulletin, v. 124, no. 1-2, p. 3-23, https://doi.org/10.1130/B30571.1.

Eberle, J.J., Gottfried, M.D., Hutchison, J.H., and Brochu, C.A., 2014, First record of Eocene bony fi shes and crocodyliforms from Canada's Western Arctic: PLoS One, v. 9, no. 5, https://doi.org/10.1371/journal.pone.0096079.

Eldrett, J.S., Greenwood, D.R., Harding, I.C., and Huber, M., 2009, Increased seasonality through the Eocene to Oligocene transition in northern high latitudes: Nature, v. 459, no. 7249, p. 969-973, https://doi.org/10.1038/nature08069

Eldrett, J.S., Greenwood, D.R., Polling, M., Brinkhuis, H., and Sluijs, A., 2014, A seasonality trigger for carbon injection at the Paleocene-Eocene Thermal Maximum: Climate of the Past, v. 10, no. 2, p. 759-769, https://doi.org/10.5194/cp-10-759-2014.

Ellison, A.M., Farnsworth, E.J., and Merkt, R.E., 1999, Origins of mangrove ecosystems and the mangrove biodiversity anomaly: Global Ecology and Biogeography, v. 8, no. 2, p. 95-115, https://doi.org/10.1046/j.1466-822X.1999.00126.x.

Engelhart, S.E., Horton, B.P., Roberts, D.H., Bryant, C.L., and Corbett, D.R., 2007, Mangrove pollen of Indonesia and its suitability as a sea-level indicator: Marine Geology, v. 242, p. 65-81, https://doi.org/10.1016/j. margeo.2007.02.020.

Espitalié, J., Deroo, G., and Marquis, F., 1985, La pyrolyse Rock-Eval et ses applications: Deuxième partie: Oil \& Gas Science and Technology, v. 40, no. 6, p. 755-784.

Fauquette, S., Guiot, J., and Suc, J.-P., 1998a, A method for climatic reconstruction of the Mediterranean Pliocene using pollen data: Palaeogeography, Palaeoclimatology, Palaeoecology, v. 144, no. 1-2, p. 183-201, https://doi.org/10.1016/S0031-0182(98)00083-2.

Fauquette, S., Quézel, P., Guiot, J., and Suc, J.-P., 1998b, Signification bioclimatique de taxonsguides du Pliocène Méditerranéen: Geobios, v. 31, no.2, p. 151-169, https://doi.org/10.1016/S00166995(98)80035-1.

Foreman, B.Z., Clementz, M.T., and Heller, P.L., 2013, Evaluation of paleoclimatic conditions east and west of the southern Canadian Cordillera in the mid-late Paleocene using bulk organic $813 \mathrm{C}$ records: Palaeogeography, Palaeoclimatology, Palaeoecology, v. 376, p. 103-113, https://doi.org/10.1016/j.palaeo.2013.02.023.

Frederiksen, N.O., Edwards, L.E., Ager, T.A., and Sheehan, T.P., 2002, Palynology of Eocene strata in the Sagavanirktok and Canning formations of the north slope of Alaska: Palynology, v. 26, p. 59-93, https://doi.org/10.2113/0260059.

Garel, S., Schnyder, J., Jacob, J., Dupuis, C., Boussafir, M., Le Milbeau, C., Storme, J.Y., Iakovleva, A.I., Yans, J., Baudin, F., Fléhoc, C., and Quesnel, F., 2013, Paleohydrological and paleoenvironmental changes recorded in terrestrial sediments of the Paleocene-Eocene boundary (Normandy, France): Palaeogeography, Palaeoclimatology, Palaeoecology, v. 376, p. 184-199, https://doi.org/10.1016/j.palaeo.2013.02.035.

Giesen, W., Wulffraat, S., Zieren, M., and Scholten, L., 2007, Mangrove guidebook for Southeast Asia: Bangkok, FAO Regional Office for Asia and the Pacific, 769 p.

Greenwood, D.R., and Basinger, J.F., 1994, The paleoecology of high-latitude Eocene swamp forests from Axel Heiberg Island, Canadian High Arctic: Review of Palaeobotany and Palynology, v. 81, p. 83-97, https://doi.org/10.1016/0034-6667(94)90128-7. 
Greenwood, D.R., and Wing, S.L., 1995, Eocene continental climates and latitudinal temperature gradients: Geology, v. 23, p. 1044-1048, https://doi.org/10.1130/00917613(1995)023<1044:ECCALT>2.3.CO;2.

Greenwood, D.R., Basinger, J.F., and Smith, R.Y., 2010, How wet was the Arctic Eocene rain forest? Estimates of precipitation from Paleogene Arctic macrofloras: Geology, v. 38, p. 15-18, https://doi.org/10.1130/G30218.1.

Grimsson, F., Zetter, R., Pedersen, G.K., Pedersen, A.K., and Denk, T., 2014, Middle Eocene palynoflora from a resinite-rich coal bed on Hareøen (Qeqetarsuatsiaq), West Greenland: 9th European Palaeobotany-Palynology Conference, Padova, Italy, Abstract Book, p. 86.

Gushulak, C.A.C., West, C.K., and Greenwood, D.R., 2016, Paleoclimate and precipitation seasonality of the Early Eocene McAbee megaflora, Kamloops Group, British Columbia: Canadian Journal of Earth Sciences, v. 53, p. 591-604, https://doi.org/10.1139/cjes-2015-0160.

Harrington, G.J., Eberle, J., LePage, B.A., Dawson, M., and Hutchison, J.H., 2011, Arctic plant diversity in the Early Eocene greenhouse: Proceedings, Biological Sciences, v. 279, p. 1515-1521, https://doi.org/10.1098/rspb.2011.1704.

Harrison, J.C., Mayr, U., McNeil, D.H., Sweet, A.R., McIntyre, D.J., Eberle, J.J., Harington, C.R., Chalmers, J.A., Dam, G., and Nohr-Hansen, H., 1999, Correlation of Cenozoic sequences of the Canadian Arctic region and Greenland; implications for the tectonic history of northern North America: Bulletin of Canadian Petroleum Geology, v. 47, no. 3, p. 223-254.

Ho, S.L., and Laepple, T., 2016, Flat meridional temperature gradient in the early Eocene in the subsurface rather than surface ocean: Nature Geoscience, v. 9, p. 606-610, https://doi.org/10.1038/ngeo2763.

Hoke, G.D., Schmitz, M.D., and Bowring, S.A., 2014, An ultrasonic method for isolating nonclay components from clay-rich material: Geochemistry Geophysics Geosystems, v. 15, p. 492-498, https://doi.org/10.1002/2013GC005125.

Holtzapffel, T., 1985, Les minéraux argileux: préparation, analyse diffractométrique et détermination, Volume 12: Société géologique du Nord, $136 \mathrm{p}$.

Hou, H.-Y., 1983, Vegetation of China with reference to its geographical distribution: Annals of the Missouri Botanical Garden, v. 70, p. 509-548, https://doi.org/10.2307/2992085.

Huber, M., and Caballero, R., 2011, The Early Eocene equable climate problem revisited: Climate of the Past, v. 7, p. 603-633, https://doi.org/10.5194/cp-7-603-2011.

Huber, M., and Goldner, A., 2012, Eocene monsoons: Journal of Asian Earth Sciences, v. 44, p. $3-$ 23, https://doi.org/10.1016/j.jseaes.2011.09.014.

Iakovleva, A.I., Brinkhuis, H., and Cavagnetto, C., 2001, Late Palaeocene-Early Eocene dinoflagellate cysts from the Turgay Strait, Kazakhstan; correlations across ancient seaways: Palaeogeography, Palaeoclimatology, Palaeoecology, v. 172, no. 3-4, p. 243-268, https://doi.org/10.1016/S0031-0182(01)00300-5.

Ioannides, N.S., and McIntyre, D.J., 1980, A preliminary palynological study of the Caribou Hills outcrop section along the Mackenzie River, District of Mackenzie: Current Research, Part A, Geological Survey of Canada Paper, p. 197-208, https://doi.org/10.4095/106203.

Jacques, F.M., Shi, G., Li, H., and Wang, W., 2014, An early-middle Eocene Antarctic summer monsoon: evidence of 'fossil climates': Gondwana Research, v. 25, no. 4, p. 1422-1428, https://doi.org/10.1016/j.gr.2012.08.007.

Jaffey, A.H., Flynn, K.F., Glendenin, L.E., Bentley, W.C., and Essling, A.M., 1971, Precision measurements of half-lives and specifi c activities of ${ }^{235} \mathrm{U}$ and ${ }^{238} \mathrm{U}$ : Physical Review C: Nuclear Physics, v. 4, p. 1889-1906, https://doi.org/10.1103/PhysRevC.4.1889.

Jahren, A.H., 2007, The Arctic forest of the middle Eocene: Annual Review of Earth and Planetary Sciences, v. 35, p. 509-540, https://doi.org/10.1146/annurev.earth.35.031306.140125.

Jakobsson, M., Mayer, L., Coakley, B., Dowdeswell, J.A., Forbes, S., Fridman, B., Hodnesdal, H., Noormets, R., Pedersen, R., Rebesco, M., Schenke, H.W., Zarayskaya, Y., Accettella, D., Armstrong, A., Anderson, R.M., Bienhoff, P., Camerlenghi, A., Church, I., Edwards, M., Gardner, J.V., Hall, J.K., Hell, B., Hestvik, O., Kristoffersen, Y., Marcussen, C., Mohammad, R., Mosher, D., Nghiem, S.V., Pedrosa, M.T., Travaglini, P.G., and Weatherall, P., 2012, The International Bathymetric Chart of the Arctic Ocean (IBCAO) Version 3.0: Geophysical Research Letters, v. 39, https://doi.org/10.1029/2012GL052219. 
Jaramillo, C., Ochoa, D., Contreras, L., Pagani, M., Carvajal-Ortiz, H., Pratt, L.M., Krishnan, S., Cardona, A., Romero, M., Quiroz, L., Rodriguez, G., Rueda, M.J., de la Parra, F., Moron, S., Green, W., Bayona, G., Montes, C., Quintero, O., Ramirez, R., Mora, G., Schouten, S., Bermudez, H., Navarrete, R., Parra, F., Alvaran, M., and Osorno, J., 2010, Effects of rapid global warming at the Paleocene-Eocene boundary on neotropical vegetation: Science, v. 330, p. 957-961, https://doi.org/10.1126/science.1193833.

Jiménez-Moreno, G., and Suc, J.-P., 2007, Middle Miocene latitudinal climatic gradient in Western Europe: evidence from pollen records: Palaeogeography, Palaeoclimatology, Palaeoecology, v. 253, p. 208-225, https://doi.org/10.1016/j.palaeo.2007.03.040.

Jones, T.D., Lunt, D.J., Schmidt, D.N., Ridgwell, A., Sluijs, A., Valdes, P.J., and Maslin, M., 2013, Climate model and proxy data constraints on ocean warming across the Paleocene-Eocene Thermal Maximum: Earth-Science Reviews, v. 125, p. 123-145, https://doi.org/10.1016/j. earscirev.2013.07.004.

Kaiho, K., Arinobu, T., Ishiwatari, R., Morgans, H.E., Okada, H., Takeda, N., Tazaki, K., Zhou, G., Kajiwara, Y., Matsumoto, R., Hirai, A., Niitsuma, N., and Wada, H., 1996, Latest Paleocene benthic foraminiferal extinction and environmental changes at Tawanui, New Zealand: Paleoceanography, v. 11, p. 447-465, https://doi.org/10.1029/96PA01021.

Kalkreuth, W., Keuser, C., Fowler, M., Li, M., McIntyre, D., Püttmann, W., and Richardson, R., 1998, The petrology, organic geochemistry and palynology of Tertiary age Eureka Sound Group coals, Arctic Canada: Organic Geochemistry, v. 29, p. 799-809, https://doi.org/10.1016/S01466380(98)00122-3.

Kalkreuth, W.D., Riediger, C.L., McIntyre, D.J., Richardson, R.J.H., Fowler, M.G., and Marchioni, D., 1996, Petrological, palynological and geochemical characteristics of Eureka Sound Group coals (Stenkul Fiord, southern Ellesmere Island, Arctic Canada): International Journal of Coal Geology, v. 30, p. 151-182, https://doi.org/10.1016/0166-5162(96)00005-5.

Kennett, J.P., and Stott, L.D., 1991, Abrupt deep sea warming, paleoceanographic changes and benthic extinctions at the end of the Paleocene: Nature, v. 353, p. 225-229, https://doi.org/10.1038/353225a0.

Kohn, M.J., 2010, Carbon isotope compositions of terrestrial C3 plants as indicators of (paleo) ecology and (paleo) climate: Proceedings of the National Academy of Sciences of the United States of America, v. 107, no. 46, p. 19691-19695, https://doi.org/10.1073/pnas.1004933107.

Kumagai, H., Sweda, T., Hayashi, K., Kojima, S., Basinger, J.F., Shibuya, M., and Fukaoa, Y., 1995, Growth-ring analysis of Early Tertiary conifer woods from the Canadian High Arctic and its paleoclimatic interpretation: Palaeogeography, Palaeoclimatology, Palaeoecology, v. 116, no. 3, p. $247-$ 262, https://doi.org/10.1016/0031-0182(94)00100-M.

Liu, Y.-S., and Basinger, J.F., 2000, Fossil Cathaya (Pinaceae) pollen from the Canadian High Arctic: International Journal of Plant Sciences, v. 161, no. 5, p. 829-847, https://doi.org/10.1086/314296.

Lo, E.Y., Duke, N.C., and Sun, M., 2014, Phylogeographic pattern of Rhizophora (Rhizophoraceae) reveals the importance of both vicariance and long-distance oceanic dispersal to modern mangrove distribution: BMC Evolutionary Biology, v. 14, no. 1, p. 83, https://doi.org/10.1186/1471-2148-14-83.

Lourens, L.J., Sluijs, A., Kroon, D., Zachos, J.C., Thomas, E., Röhl, U., Bowles, J., and Raffi , I., 2005, Astronomical pacing of late Palaeocene to early Eocene global warming events: Nature, v. 435, no. 7045 , p. 1083-1087, https://doi.org/10.1038/nature03814.

Magioncalda, R., Dupuis, C., Smith, T., Steurbaut, E., and Gingerich, P.D., 2004, Paleocene-Eocene carbon isotope excursion in organic carbon and pedogenic carbonate: Direct comparison in a continental stratigraphic section: Geology, v. 32, no. 7, p. 553-556, https://doi.org/10.1130/G20476.1.

Mao, L., Batten, D.J., Fujiki, T., Li, Z., Dai, L., and Weng, C., 2012, Key to mangrove pollen and spores of southern China: an aid to palynological interpretation of Quaternary deposits in the South China Sea: Review of Palaeobotany and Palynology, v. 176, p. 41-67, https://doi.org/10.1016/j.revpalbo.2012.03.004.

Mattinson, J.M., 2005, Zircon U-Pb chemical abrasion ("CA-TIMS") method: combined annealing and multi-step partial dissolution analysis for improved precision and accuracy of zircon ages: Chemical Geology, v. 220, p. 47-66, https://doi.org/10.1016/j.chemgeo.2005.03.011. 
McArthur, A.D., Kneller, B.C., Souza, P.A., and Kuchle, J., 2016, Characterization of deep-marine channel-levee complex architecture with palynofacies: An outcrop example from the Rosario Formation, Baja California, Mexico: Marine and Petroleum Geology, v. 73, p. 157-173, https://doi.org/10.1016/j.marpetgeo.2016.02.030.

McIver, E.E., and Basinger, J.F., 1999, Early Tertiary floral evolution in the Canadian high Arctic: Annals of the Missouri Botanical Garden, v. 86, no. 2, p. 523-545, https://doi.org/10.2307/2666184.

McLean, N.M., Condon, D.J., Schoene, B., and Bowring, S.A., 2015, Evaluating uncertainties in the calibration of isotopic reference materials and multi-element isotopic tracers (EARTHTIME Tracer Calibration Part II): Geochimica et Cosmochimica Acta, v. 164, p. 481-501, https://doi.org/10.1016/j.gca.2015.02.040.

McNeil, D.H., 1989, Foraminiferal zonation and biofacies analysis of Cenozoic strata in the Beaufort-Mackenzie Basin of Arctic Canada: Current Research, Part G, Geological Survey of Canada, Paper no. 89-1G, p. 203-223, https://doi.org/10.4095/127602.

McNeil, D.H., 1997, New foraminifera from the Upper Cretaceous and Cenozoic of the BeaufortMackenzie Basin of Arctic Canada: Cushman Foundation for Foraminiferal Research, Special Publication no. 35, 95 p.

McNeil, D.H., and Parsons, M.G., 2013, The Paleocene-Eocene thermal maximum in the Arctic Beaufort-Mackenzie Basin-Palynomorphs, carbon isotopes and benthic foraminiferal turnover: Bulletin of Canadian Petroleum Geology, v. 61, no. 2, p. 157-186, https://doi.org/10.2113/gscpgbull.61.2.157.

Moore, D.M., and Reynolds, R.C., 1997, X-ray Diffraction and the Identification and Analysis of Clay Minerals: Oxford: Oxford University Press, 378 p.

Moran, K., Backman, J., Brinkhuis, H., Clemens, S.C., Cronin, T., Dickens, G.R., Eynaud, F., Gattacceca, J., Jakobsson, M., Jordan, R.W., Kaminski, M., King, J., Koc, N., Krylov, A., Martinez, N., Matthiessen, J., Mc Inroy, D., Moore, T.C., Onodera, J., O'Regan, M., Pälike, H., Rea, B., Rio, D., Sakamoto, T., Smith, D.C., Stein, R., St John, K., Suto, I., Suzuki, N., Takahashi, K., Watanabe, M., Yamamoto, M., Farrell, J., Frank, M., Kubik, P., Jokat, W., and Kristoffersen, Y., 2006, The Cenozoic palaeo environment of the Arctic Ocean: Nature, v. 441, p. 601-605, https://doi.org/10.1038/nature04800.

Nasdala, L., Lengauer, C.L., Hanchar, J.M., Kronz, A., Wirth, R., Blanc, P., Kennedy, A.K., and Seydoux-Guillaume, A.M., 2002, Annealing radiation damage and the recovery of cathodoluminescence: Chemical Geology, v. 191, p. 121-140, https://doi.org/10.1016/S00092541(02)00152-3.

Nix, H., 1982, Environmental determinants of biogeography and evolution in Terra Australis, in Barker W. R., and Greenslade, P.J.M., eds., Evolution of the Flora and fauna of Arid Australia, Frewville: Peacock Publishing, p. 47-66.

Norris, D.K., and Whitman, G.S., 1981, Geology, Aklavik, District of Mackenzie: Geological Survey of Canada, https://doi.org/10.4095/109706.

Parsons, M.G., 2000, Palynology of Paleogene strata in the Caribou Hills, Beaufort-Mackenzie Basin, northern Canada [Ph.D. thesis]: University of Toronto, $604 \mathrm{p}$.

Parsons, M.G., and Norris, G., 1999, Paleogene fungi from the Caribou Hills, Mackenzie Delta, northern Canada: Palaeontographica Abteilung B, p. 77-167.

Pearson, P.N., and Palmer, M.R., 2000, Atmospheric carbon dioxide concentrations over the past 60 million years: Nature, v. 406, p. 695-699, https://doi.org/10.1038/35021000.

Peppe, D., Royer, D.L., Cariglino, B., Oliver, S.Y., Newman, S., Leight, E., Enikolopov, G., Fernandez-Burgos, M., Herrera, F., Adams, J.M., Correa, E., Currano, E.D., Erickson, J.M., Hinojosa, L.F., Hoganson, J.W., Iglesias, A., Jaramillo, C.A., Johnson, K.R., Jordan, G.J., Kraft, N.J.B., Lovelock, E.C., Lusk, C.H., Niinemets, U., Penuelas, J., Rapson, G., Wing, S.L., and Wright, I.J., 2011, Sensitivity of leaf size and shape to climate: global patterns and paleoclimatic applications: The New Phytologist, v. 190, p. 724-739, https://doi.org/10.1111/j.1469-8137.2010.03615.x.

Pole, M.S., and Macphail, M.K., 1996, Eocene Nypa from Regatta Point, Tasmania: Review of Palaeobotany and Palynology, v. 92, no. 1-2, p. 55-67, https://doi.org/10.1016/0034-6667(95)00099-2.

Popescu, S.-M., 2002, Repetitive changes in Early Pliocene vegetation revealed by high-resolution pollen analysis: revised cyclostratigraphy of southwestern Romania: Review of Palaeobotany and Palynology, v. 120, p. 181-202, https://doi.org/10.1016/S0034-6667(01)00142-7. 
Popescu, S.-M., Krijgsman, W., Suc, J.-P., Clauzon, G., Mărunţeanu, M., and Nica, T., 2006, Pollen record and integrated high-resolution chronology of the early Pliocene Dacic Basin (southwestern Romania): Palaeogeography, Palaeoclimatology, Palaeoecology, v. 238, p. 78-90, https://doi.org/10.1016/j.palaeo.2006.03.019.

Price, L.L., McNeil, D.H., and Ioannides, N.S., 1980, Revision of the Tertiary Reindeer Formation in the Caribou Hills, District of Mackenzie, in Current Research, Part B: Geological Survey of Canada, Paper 80-1B, p. 179-184.

Pross, J., Contreras, L., Bijl, P.K., Greenwood, D.R., Bohaty, S.M., Schouten, S., Bendle, J.A., Röhl, U., Tauxe, L., Raine, J.I., Huck, C.E., van de Flierdt, T., Jamieson, S.S.R., Stickley, C.E., van de Schootbrugge, B., Escutia, C., Brinkhuis, H., and Integrated Ocean Drilling Program Expedition 318 Scientists, 2012, Persistent near-tropical warmth on the Antarctic continent during the early Eocene epoch: Nature, v. 488, p. 73-77, https://doi.org/10.1038/nature11300.

Quisthoudt, K., Schmitz, N., Randin, C.F., Dahdouh-Guebas, F., Robert, E.M., and Koedam, N., 2012, Temperature variation among mangrove latitudinal range limits worldwide: Trees (Berlin), v. 26, no. 6, p. 1919-1931, https://doi.org/10.1007/s00468-012-0760-1.

R Core Team, 2013, R: A language and environment for statistical computing: R Foundation for Statistical Computing, Vienna, Austria, http://www.R-project.org/.

Reinhardt, L., Estrada, S., Andruleit, H., Dohrmann, R., Piepjohn, K., von Gosen, W., Davis, D.W., and Davis, B., 2013, Altered volcanic ashes in Palaeocene and Eocene sediments of the Eureka Sound Group (Ellesmere Island, Nunavut, Arctic Canada): Zeitschrift der Deutschen Gesellschaft für Geowissenschaften, v. 164, no. 1, p. 131-147, https://doi.org/10.1127/1860-1804/2013/0004.

Ridgway, K.D., Sweet, A.R., and Cameron, A.R., 1995, Climatically induced floristic changes across the Eocene-Oligocene transition in the northern high latitudes, Yukon Territory, Canada: Geological Society of America Bulletin, v. 107, p. 676-696, https://doi.org/10.1130/0016-7606 (1995) 107<0676:CIFCAT>2.3.CO;2.

Robert, C., and Kennett, J.P., 1992, Paleocene and Eocene kaolinite distribution in the South Atlantic and Southern Ocean: Antarctic climatic and paleoceanographic implications: Marine Geology, v. 103, no. 1-3, p. 99-110, https://doi.org/10.1016/0025-3227(92)90010-F.

Robert, C., and Kennett, J.P., 1994, Antarctic subtropical humid episode at the Paleocene-Eocene boundary: Clay-mineral evidence: Geology, v. 22, p. 211-214, https://doi.org/10.1130/00917613(1994)022<0211:ASHEAT >2.3.CO;2.

Roberts, C., LeGrande, A., and Tripati, A., 2009, Climate sensitivity to Arctic seaway restriction during the early Paleogene: Earth and Planetary Science Letters, v. 286, p. 576-585, https://doi.org/10.1016/j.epsl.2009.07.026.

Rögl, F., 1999, Mediterranean and Paratethys palaeogeography during the Oligocene and Miocene, in Agustí, J., ed., Hominoid evolution and climatic change in Europe, Part 1: Cambridge University Press, p. 8-22, https://doi.org/10.1017/CBO9780511542329.002.

Röhl, U., Westerhold, T., Bralower, T.J., and Zachos, J.C., 2007, On the duration of the PaleoceneEocene thermal maximum (PETM): Geochemistry Geophysics Geosystems, v. 8, https://doi.org/10.1029/2007GC001784.

Schmitz, M.D., and Davydov, V.I., 2012, Quantitative radiometric and biostratigraphic calibration of the global Pennsylvanian-Early Permian time scale: Geological Society of America Bulletin, v. 124, p. 549-577, https://doi.org/10.1130/B30385.1.

Schmitz, M.D., and Schoene, B., 2007, Derivation of isotope ratios, errors and error correlations for $\mathrm{U}-\mathrm{Pb}$ geochronology using ${ }^{205} \mathrm{~Pb}-{ }^{235} \mathrm{U}-\left({ }^{233} \mathrm{U}\right)$-spiked isotope dilution thermal ionization mass spectrometric data: Geochemistry Geophysics Geosystems, v. 8, no. 8, https://doi.org/10.1029/2006GC001492.

Schouten, S., Woltering, M., Rijpstra, W.I.C., Sluijs, A., Brinkhuis, H., and Damsté, J.S.S., 2007, The Paleocene-Eocene carbon isotope excursion in higher plant organic matter: Differential fractionation of angiosperms and conifers in the Arctic: Earth and Planetary Science Letters, v. 258, no. 3, p. 581-592, https://doi.org/10.1016/j.epsl.2007.04.024.

Schubert, B.A., Jahren, A.H., Eberle, J.J., Sternberg, L.S., and Eberth, D.A., 2012, A summertime rainy season in the Arctic forests of the Eocene: Geology, v. 40, no. 6, p. 523-526, https://doi.org/10.1130/G32856.1. 
Shukla, A., Mehrotra, R.C., Spicer, R.A., Spicer, T.E., and Kumar, M., 2014, Cool equatorial terrestrial temperatures and the South Asian monsoon in the Early Eocene: evidence from the Gurha Mine, Rajasthan, India: Palaeogeography, Palaeoclimatology, Palaeoecology, v. 412, p. 187-198, https://doi.org/10.1016/j.palaeo.2014.08.004.

Sluijs, A., Schouten, S., Pagani, M., Woltering, M., Brinkhuis, H., Damsté, J.S.S., and Moran, K., 2006, Subtropical Arctic Ocean temperatures during the Palaeocene/Eocene thermal maximum: Nature, v. 441, p. 610-613, https://doi.org/10.1038/nature04668.

Sluijs, A., Röhl, U., Schouten, S., Brumsack, H.J., Sangiorgi, F., Sinninghe Damsté, J.S., and Brinkhuis, H., 2008, Arctic late Paleocene-early Eocene paleoenvironments with special emphasis on the Paleocene-Eocene thermal maximum (Lomonosov Ridge, Integrated Ocean Drilling Program Expedition 302): Paleoceanography, v. 23, no. 1, https://doi.org/10.1029/2007PA001495.

Sluijs, A., Schouten, S., Donders, T.H., Schoon, P.L., Röhl, U., Reichart, G.J., and Brinkhuis, H., 2009, Warm and wet conditions in the Arctic region during Eocene Thermal Maximum 2: Nature Geoscience, v. 2, no. 11, p. 777-780, https://doi.org/10.1038/ngeo668.

Smith, R.Y., Basinger, J.F., and Greenwood, D.R., 2012, Early Eocene plant diversity and dynamics in the Falkland flora, Okanagan Highlands, British Columbia, Canada: Palaeobiodiversity and Palaeoenvironments, v. 92, p. 309-328, https://doi.org/10.1007/s12549-011-0061-5.

Somboon, J.R.P., 1990, Palynological study of mangrove and marine sediments of the Gulf of Thailand: Journal of Southeast Asian Earth Sciences, v. 4, no. 2, p. 85-97, https://doi.org/10.1016/07439547(90)90008-2.

Spicer, R.A., Yang, J., Herman, A.B., Kodrul, T., Maslova, N., Spicer, T.E.V., Aleksandrova, G., and Jin, J., 2016, Asian Eocene monsoons as revealed by leaf architectural signatures: Earth and Planetary Science Letters, v.449, p. 61-68, https://doi.org/10.1016/j.epsl.2016.05.036.

Stap, L., Lourens, L.J., Thomas, E., Sluijs, A., Bohaty, S., and Zachos, J.C., 2010, High-resolution deep-sea carbon and oxygen isotope records of Eocene Thermal Maximum 2 and H2: Geology, v. 38, no. 7, p. 607-610, https://doi.org/10.1130/G30777.1.

Stein, R., Boucsein, B., and Meyer, H., 2006, Anoxia and high primary production in the Paleogene central Arctic Ocean: First detailed records from Lomonosov Ridge: Geophysical Research Letters, v. 33, https://doi.org/10.1029/2006GL026776.

Stewart, G.R., Turnbull, M.H., Schmidt, S., and Erskine, P.D., 1995, ${ }^{13} \mathrm{C}$ natural abundance in plant communities along a rainfall gradient: a biological integrator of water availability: Australian Journal of Plant Physiology, v. 22, no. 1, p. 51-55, https://doi.org/10.1071/PP9950051.

Storme, J.Y., Dupuis, C., Schnyder, J., Quesnel, F., Garel, S., Iakovleva, A.I., Iacumin, P., Di Matteo, A., Sebilo, M., and Yans, J., 2012a, Cycles of humid-dry climate conditions around the P/E boundary: new stable isotope data from terrestrial organic matter in Vasterival section (NW France): Terra Nova, v. 24, no. 2, p. 114-122, https://doi.org/10.1111/j.1365-3121.2011.01044.x.

Storme, J.Y., Devleeschouwer, X., Schnyder, J., Cambier, G., Baceta, J.I., Pujalte, V., Di Matteo, A., Iacumin, P., and Yans, J., 2012b, The Palaeocene/Eocene boundary section at Zumaia (BasqueCantabric Basin) revisited: new insights from high-resolution magnetic susceptibility and carbon isotope chemostratigraphy on organic matter ( $\square$ 13Corg): Terra Nova, v. 24, no. 4, p. 310-317, https://doi.org/10.1111/j.1365-3121.2012.01064.x.

Suan, G., Popescu, S.M., Suc, J.P., Schnyder, J., Fauquette, S., Baudin, F., Yoon, D., Piepjohn, K., Sobolev, N.N., and Labrousse, L., 2017, Subtropical climate conditions and mangrove growth in Arctic Siberia during the early Eocene: Geology, v. 45, no. 6, p. 539-542, https://doi.org/10.1130/G38547.1.

Sunderlin, D., Loope, G., Parker, N.E., and Williams, C.J., 2011, Paleoclimatic and paleoecological implications of the Paleocene-Eocene fossil leaf assemblage, Chickaloon Formation, Alaska: Palaios, v. 26, p. 335-345, https://doi.org/10.2110/palo.2010.p10-077r.

Thomas, E., 2008, Descent into the Icehouse: Geology, v. 36, no. 2, p. 191-192, https://doi.org/10.1130/focus022008.1.

Thomas, E., Zachos, J.C., and Bralower, T.J., 2000, Deep-sea environments on a warm earth: Latest Paleocene-early Eocene, in Huber, B., MacLeod, K., and Wing, S., eds., Warm Climates in Earth History: Cambridge, Cambridge University Press, p. 132-160, https://doi.org/10.1017/CBO9780511564512.006.

Tramoy, R., Salpin, M., Schnyder, J., Person, A., Sebilo, M., Yans, J., Vaury, V., Fozzani, J., and Bauer, H., 2016, Stepwise palaeoclimate change across the Eocene-Oligocene transition recorded in 
continental NW Europe by mineralogical assemblages and $\delta^{15}$ Norg (Rennes Basin, France): Terra Nova, v. 28, no. 3, p. 212-220, https://doi.org/10.1111/ter.12212.

Tyson, R.V., 1995, Sedimentary Organic Matter: Organic Facies and Palynofacies: London, Chapman and Hall, 615 p., https://doi.org/10.1007/978-94-011-0739-6.

Vandenberghe, N., Hilgen, F.J., Speijer, R.P., Ogg, J.G., Gradstein, F.M., Hammer, O., Hollis, C.J., and Hooker, J.J., 2012, The Paleogene period, in Gradstein, F. M., Ogg, J. G., Schmitz, M. D., and Ogg, G. M. eds., The Geologic Time Scale 2012, vol. 1: Elsevier, p. 855-921, https://doi.org/10.1016/B9780-444-59425-9.00028-7.

van der Burgh, J., Collinson, M.E., van Konijnenburg-van Cittert, J.H., Barke, J., and Brinkhuis, H., 2013, The freshwater fern Azolla (Azollaceae) from Eocene Arctic and Nordic Sea sediments: New species and their stratigraphic distribution: Review of Palaeobotany and Palynology, v. 194, p. 50-68, https://doi.org/10.1016/j.revpalbo.2013.02.002.

van Hinsbergen, D.J.J., de Groot, L.V., van Schaik, S.J., Spakman, W., Bijl, P.K., Sluijs, A., Langereis, C.G., and Brinkhuis, H., 2015, A paleolatitude calculator for paleoclimate studies: PLoS One, v. 10, no. 6, https://doi.org/10.1371/journal.pone.0126946.

Vavrek, M.J., Evans, D.C., Braman, D.R., Campione, N.E., and Zazula, G.D., 2012, A Paleogene flora from the upper Bonnet Plume Formation of northeast Yukon Territory, Canada: Canadian Journal of Earth Sciences, v. 49, no. 3, p. 547-558, https://doi.org/10.1139/e11-073.

Velde, B.B., and Meunier, A., 2008, The Origin of Clay Minerals in Soils and Weathered Rocks: Springer Science \& Business Media, 406 p., https://doi.org/10.1007/978-3-540-75634-7.

Walter, H., 1984, Vegetation of the Earth: Stuttgart, Springer-Verlag, 318 p.

Wang, C.-W., 1961, The Forests of China with a Survey of Grassland and Desert Vegetation: Cambridge, Massachusetts, Harvard University Press, Maria Moors Cabot Foundation Publication no. $5,313 \mathrm{p}$.

Weijers, J.W., Schouten, S., Sluijs, A., Brinkhuis, H., and Damsté, J.S.S., 2007, Warm arctic continents during the Palaeocene-Eocene thermal maximum: Earth and Planetary Science Letters, v. 261, no. 1, p. 230-238, https://doi.org/10.1016/j.epsl.2007.06.033.

West, C.K., Greenwood, D.R., and Basinger, J.F., 2015, Was the Arctic Eocene 'rainforest' monsoonal? Estimates of seasonal precipitation from early Eocene megafl oras from Ellesmere Island, Nunavut: Earth and Planetary Science Letters, v. 427, p. 18-30, https://doi.org/10.1016/j.epsl.2015.06.036.

Westerhold, T., Röhl, U., Frederichs, T., Agnini, C., Raffi , I., Zachos, J.C., and Wilkens, R.H., 2017, Astronomical calibration of the Ypresian timescale: implications for seafloor spreading rates and the chaotic behavior of the solar system?: Climate of the Past, v. 13, p. 1129-1152, https://doi.org/10.5194/cp-13-1129-2017.

White, J.M., 2006, Palynology, age, correlation and paleoclimatology from JAPEX/JNOC/GSC Mallik 2L-38 gas hydrate research well and the significance for gas hydrates: a new approach: Geological Survey of Canada, Open File 5088, 75 p., https://doi.org/10.4095/222149.

Wilf, P., 2000, Late Paleocene-early Eocene climate changes in southwestern Wyoming: Paleobotanical analysis: Geological Society of America Bulletin, v. 112, no. 2, p. 292-307, https://doi.org/10.1130/0016-7606(2000)112<292:LPECCI>2.0.CO;2.

Wing, S.L., and Greenwood, D.R., 1993, Fossils and fossil climate: the case for equable continental interiors in the Eocene: Philosophical Transactions of the Royal Society of London, Series B, Biological Sciences, v. 341, p. 243-252, https://doi.org/10.1098/rstb.1993.0109.

Wynn, J.G., Bird, M.I., and Wong, V.N., 2005, Rayleigh distillation and the depth profi le of 13C/12C ratios of soil organic carbon from soils of disparate texture in Iron Range National Park, Far North Queensland, Australia: Geochimica et Cosmochimica Acta, v. 69, no. 8, p. 1961-1973, https://doi.org/10.1016/j.gca.2004.09.003.

Zachos, J.C., Stott, L.D., and Lohmann, K.C., 1994, Evolution of early Cenozoic marine temperatures: Paleoceanography, v. 9, no. 2, p. 353-387, https://doi.org/10.1029/93PA03266.

Zachos, J., Pagani, M., Sloan, L., Thomas, E., and Billups, K., 2001, Trends, rhythms, and aberrations in global climate $65 \mathrm{Ma}$ to present: Science, v. 292, no. 5517, p. 686-693, https://doi.org/10.1126/science.1059412.

Zachos, J.C., Röhl, U., Schellenberg, S.A., Sluijs, A., Hodell, D.A., Kelly, D.C., Thomas, E., Nicolo, M., Raffi , I., Lourens, L.J., McCarren, H., and Kroon, D., 2005, Rapid acidifi cation of the ocean during 
the Paleocene-Eocene thermal maximum: Science, v. 308, no. 5728, p. 1611-1615, https://doi.org/10.1126/science.1109004.

Zachos, J.C., Dickens, G.R., and Zeebe, R.E., 2008, An early Cenozoic perspective on greenhouse warming and carbon-cycle dynamics: Nature, v. 451, no. 7176, p. 279-283, https://doi.org/10.1038/nature06588.

Zaporozhets, N.I., and Akhmetiev, M.A., 2013, The Middle and Upper Eocene sections of the Omsk Trough, West Siberian Platform: palynological, stratigraphic, hydrologic and climatic aspects: Stratigraphy and Geological Correlation, v. 21, no. 1, p. 107-130, https://doi.org/10.1134/S0869593813010061. 


\section{FIGURES}

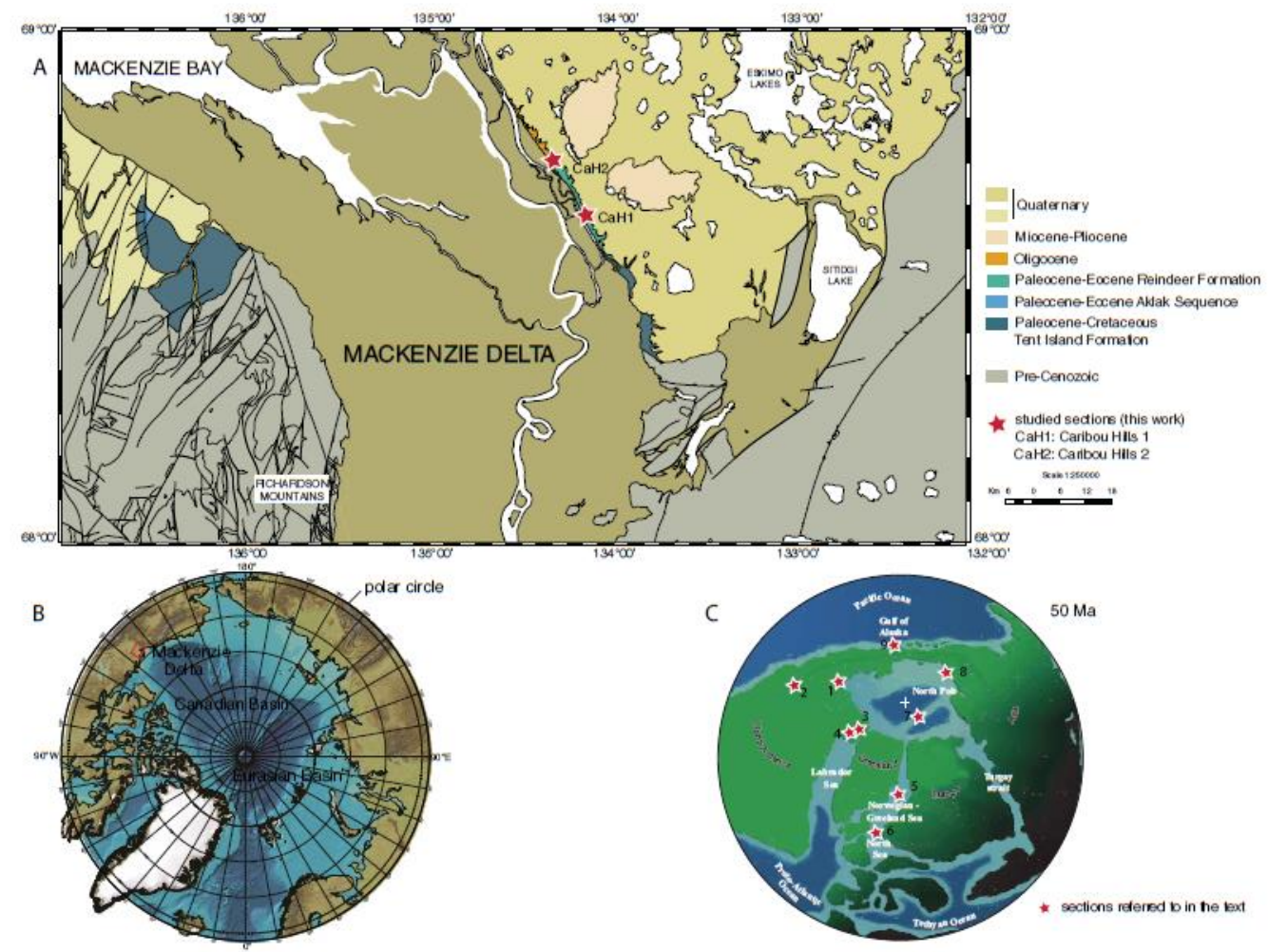

Figure 1. (A) Simplified geological map of the Mackenzie Delta with location of the studied sections (red stars) (modified from Norris and Whitman, 1981). (B) Map of the Arctic Basin with location of the Mackenzie Delta shown in the red box (Jakobsson et al., 2012). (C) Paleogeographic map of the Arctic during the Eocene and location of the studied sites referred to in Table 4 (red stars) (modified from Brinkhuis et al., 2006). The cross represents the North Pole.

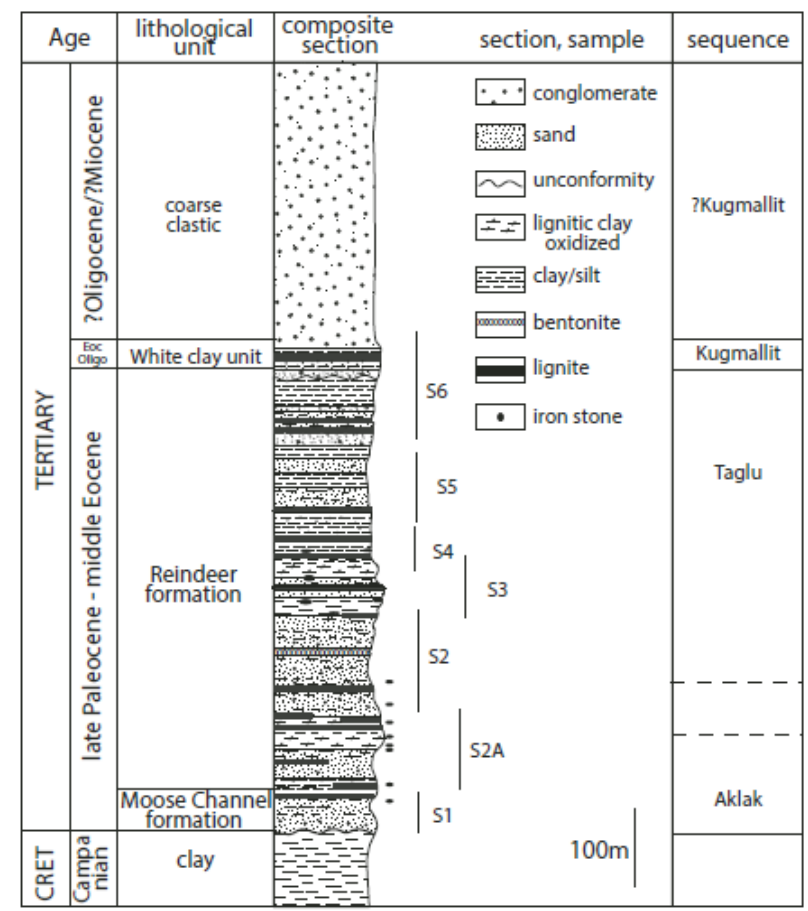

Figure 2. Composite section of the Caribou Hills outcrop showing the sections studied in the past 30 years by various authors and the interpreted long-term sedimentary sequences (after Parsons, 2000; Price et al., 1980). 


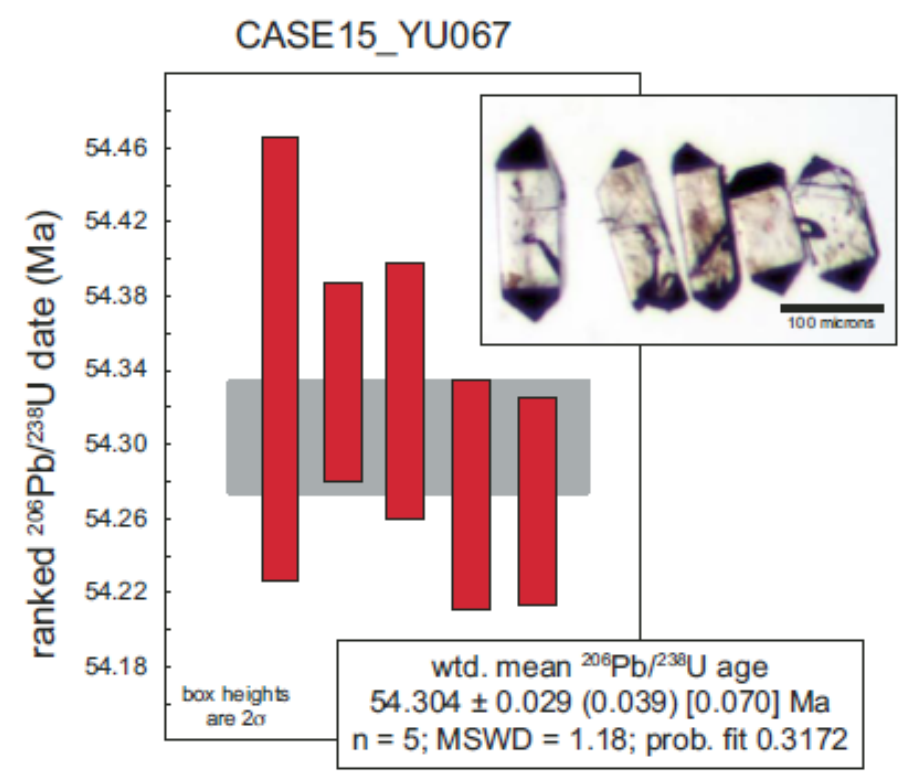

Figure 3. Results of U-Pb zircon analyses (ID-TIMS) of the bentonite layer (sample CASE15_YU067) in section CaH1. Cathodoluminescence photograph illustrates the zircons from analyzed bentonite layer.
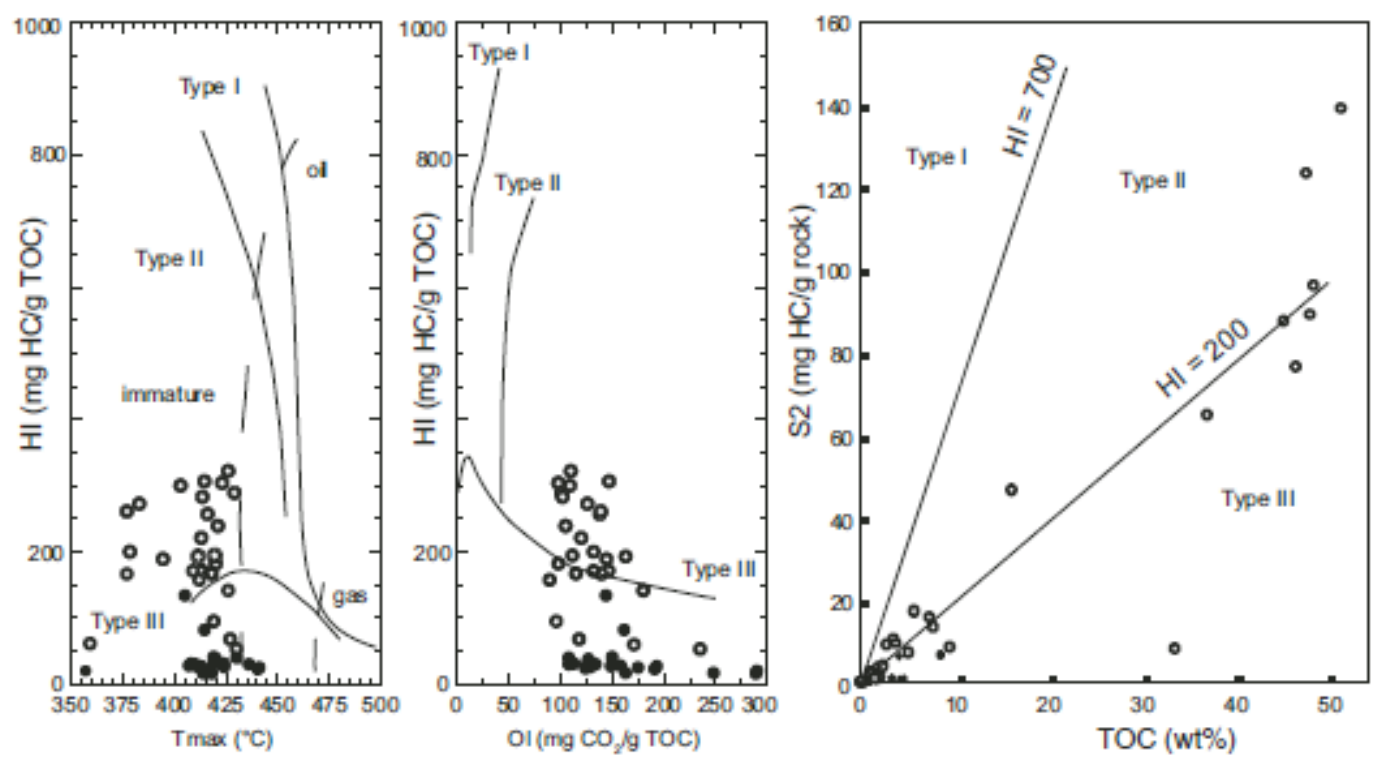

Figure 4. Rock Eval results of the two Caribou Hills sections. HI-Hydrogen Index in mg HC/g TOC; OI-Oxygen Index in $\mathrm{mg} \mathrm{CO} / \mathrm{g}$ TOC; S2 - mg HC/g rock; Tmax - degree of thermogenic maturation of the kerogen in ${ }^{\circ} \mathrm{C}$. Type I- lacustrine organic matter. Type II-marine organic matter. Type III — terrestrial organic matter. Filled circles - CaH1; Open circles$\mathrm{CaH} 2$. For the two sections, the organic matter corresponds to a Type III and is immature. 

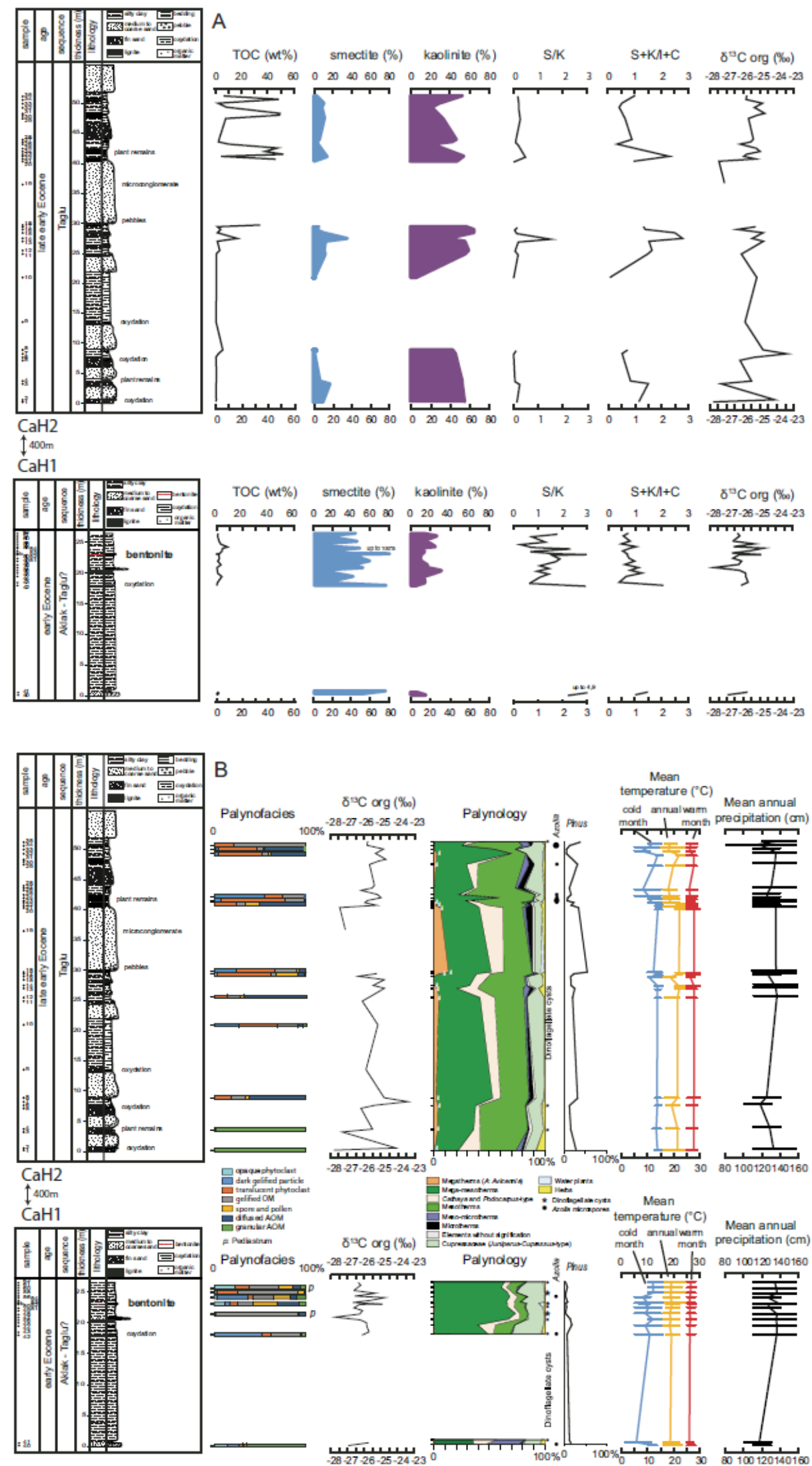

Figure 5 (A) From left to right, for the two sections of Caribous Hills: results of Rock Eval pyrolysis, clay mineralogy, and stable carbon isotope geochemistry. (B) From left to right, for the two sections of Caribou Hills: results of palynofacies, stable carbon isotope geochemistry, palynology, and climatic parameters. $\mathrm{b}$ — bentonite; $\mathrm{p}$-Pediastrum; A-Avicennia; stars - dinoflagellate cysts; dots-Azolla microspores. 

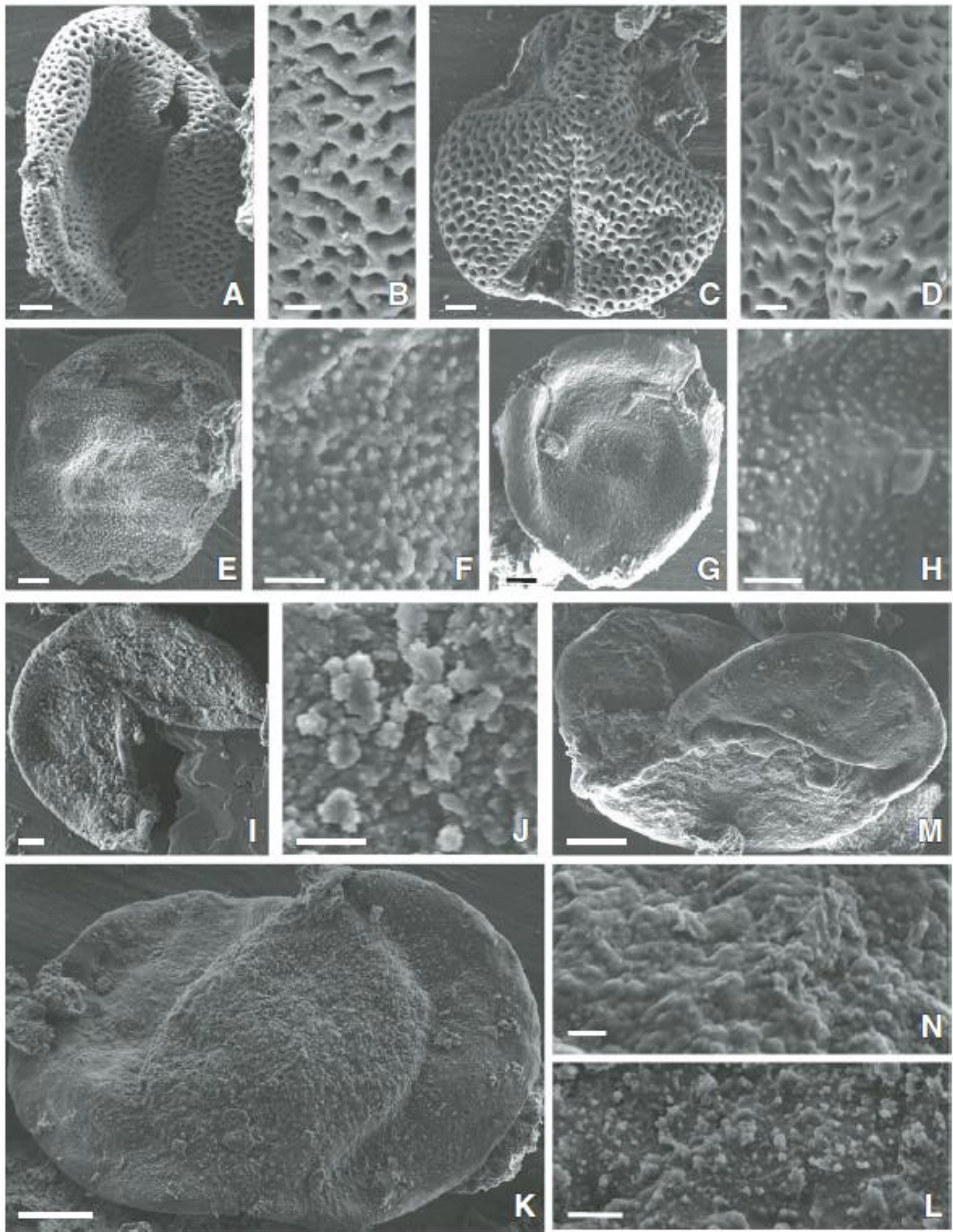

Figure 6. Photographs of pollen grains using a scanning electronic microscope (CaH2 section, sample 8). (A-D) Avicennia (Acanthaceae). (A) Equatorial view showing an aperture (scale bar $=2 \mu \mathrm{m}$ ). (B) Detail of the reticulate ornamentation in the mesocolpium (scale bar $=1 \mu \mathrm{m}$ ). (C) Polar view showing the small polar area (scale bar $=2 \mu \mathrm{m})$. (D) Detail of the reticulate ornamentation at the pole (scale bar $=1 \mu \mathrm{m}$ ). (E-F) Alfaroa-type (Juglandaceae). (E) Polar view showing the three pores (scale bar $=2 \mu \mathrm{m})$. (F) Sculpture made of dense spinules (scale bar $=1 \mu \mathrm{m})$. $(\mathrm{G}-\mathrm{H})$ Engelhardia $($ Juglandaceae). $(\mathrm{G})$ Polar view showing the three pores (scale bar $=2 \mu \mathrm{m}$ ). (H) Sculpture made of scattered and uniformly distributed spinules (scale bar $=1 \mu \mathrm{m})$. (I-J) Glyptostrobus-Taxodium-type (Glyptostrobus) (Cupressaceae). (I) Pollen showing a small papilla (scale bar $=2 \mu \mathrm{m}$ ). (J) Detail of its composite heteromorphic ornamentation (large verrucae integrated within numerous smaller ones) (scale bar $=1 \mu \mathrm{m})$. $(\mathrm{K}-\mathrm{L})$ Cathaya (Pinaceae). (K) Proximal view showing the haploxylonoid outline of sacci and corpus (scale bar $=8 \mu \mathrm{m}$ ). (L) Low spinules on the corpus (scale bar $=1 \mu \mathrm{m})$. (M-N) Pinus haploxylon-type (Pinaceae). (M) Profi le view showing the haploxylonoid outline of sacci and corpus (scale bar $=8 \mu \mathrm{m}$ ). $(\mathrm{N})$ Verrucae on the corpus (scale bar $=1 \mu \mathrm{m})$. 


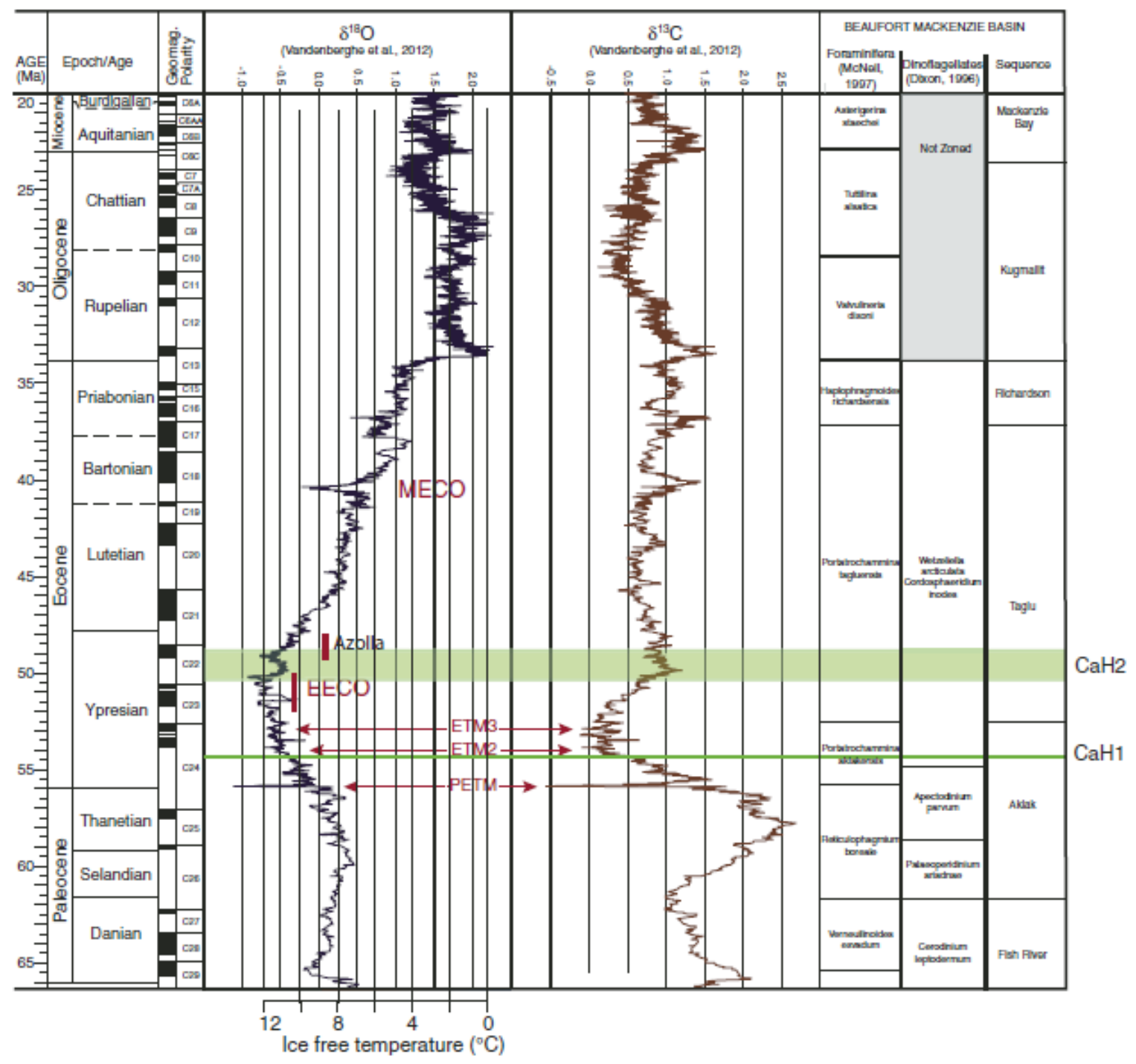

Figure 7. Proposed stratigraphic correlation of the two studied sections (green lines) based on bentonite dating, the pollen assemblages, and the climatic clues of the total set of analyses. The Paleocene-Eocene hyperthermal events are indicated in red on the stable isotopes curve. PETM-Paleocene-Eocene Thermal Maximum; ETM2-Eocene Thermal Maximum 2; ETM3-Eocene Thermal Maximum 3; EECO_Early Eocene Climatic Optimum; MECO_Middle Eocene Climatic Optimum. The Azolla event is indicated in black. 


\section{TABLES}

TABLE 1. U-PB ISOTOPIC DATA

\begin{tabular}{|c|c|c|c|c|c|c|c|c|c|c|c|c|c|c|c|c|c|c|c|c|}
\hline \multirow[b]{2}{*}{ Grain } & \multirow[b]{2}{*}{$\mathrm{Th} / \mathrm{U}$} & \multirow[b]{2}{*}{$\begin{array}{c}{ }^{20} \mathrm{~Pb}^{*} \\
\times 10^{-13} \\
\mathrm{~mol}\end{array}$} & \multirow[b]{2}{*}{$\begin{array}{l}\mathrm{mol}_{20} \\
20 \mathrm{~Pb}^{*}\end{array}$} & \multirow[b]{2}{*}{$\begin{array}{l}\mathrm{Pb}^{*} / \\
\mathrm{Pbc}^{2}\end{array}$} & \multirow[b]{2}{*}{$\begin{array}{l}\mathrm{Pbc} \\
(\mathrm{pg})\end{array}$} & \multirow[b]{2}{*}{$\begin{array}{l}{ }^{20} \mathrm{pb} / \\
{ }^{20 \mathrm{PPb}}\end{array}$} & \multicolumn{7}{|c|}{ Radiogenic ksotopic Ratios } & \multirow{3}{*}{ 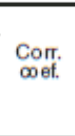 } & \multicolumn{6}{|c|}{ Radiogenic lsobpic Dates } \\
\hline & & & & & & & $\begin{array}{l}{ }^{20 \mathrm{pp} /} / \\
2 \mathrm{mpb}\end{array}$ & $\begin{array}{l}{ }^{200} \mathrm{~Pb} / \\
{ }^{200 \mathrm{PPb}}\end{array}$ & $\%$ err. & ${ }^{200} \mathrm{~Pb}$ & $\%$ err. & $\begin{array}{c}{ }^{2 e t} \mathrm{~Pb} / \\
{ }^{2 \times} \mathrm{U}\end{array}$ & \% err. & & $\begin{array}{l}{ }^{200} \mathrm{~Pb} / \\
{ }^{2000} \mathrm{~Pb}\end{array}$ & \pm & $\begin{array}{l}{ }^{200} \mathrm{PP} / \\
{ }^{2 x} \mathrm{U}\end{array}$ & \pm & $\begin{array}{l}{ }^{500} \mathrm{tp} / \\
20 \mathrm{U} /\end{array}$ & \pm \\
\hline (a) & (b) & (c) & (c) & (c) & (c) & (d) & (e) & (e) & (f) & (e) & (f) & (e) & (f) & & (g) & (f) & (g) & (f) & (g) & (f) \\
\hline \multicolumn{21}{|c|}{ CASE15_YU067 } \\
\hline$z 4$ & 0.511 & 0.1663 & $95.61 \%$ & 7 & 0.63 & 414 & 0.164 & 0.046151 & 2.383 & 0.053872 & 2.520 & 0.008466 & 0.219 & 0.651 & 5 & 57 & 53.3 & 1.3 & 54.35 & 0.12 \\
\hline 25 & 0.457 & 0.2250 & $7.67 \%$ & 12 & 44 & 776 & 0.147 & 0.046833 & 0.665 & 0.054656 & 0.722 & 0.008464 & 0.099 & 0.6 & 41 & 100 & 54.0 & 0.4 & 54.33 & 0.05 \\
\hline 23 & 0.384 & 0.1462 & $4.73 \%$ & 5 & 0.67 & 345 & 0.123 & 0.047153 & 1.097 & 0.055025 & 1.183 & 0.008463 & 0.127 & 0.717 & 57 & 26 & 54.4 & 0.6 & 54.33 & 0.07 \\
\hline$z 2$ & 0.481 & 0.1648 & $97.32 \%$ & 11 & 0.38 & 673 & 0.154 & 0.045801 & 0.826 & 0.053392 & 0.891 & 0.008455 & 0.113 & 0.623 & -13 & 20 & 52.8 & 0.5 & 54.27 & 0.06 \\
\hline$z 1$ & 0.398 & 0.1392 & $97.43 \%$ & 11 & 0.30 & 703 & 0.126 & 0.045889 & 0.827 & 0.053491 & 0.892 & 0.008454 & 0.104 & 0.663 & -8 & 20 & 52.9 & 0.5 & 54.27 & 0.06 \\
\hline \multicolumn{21}{|c|}{ 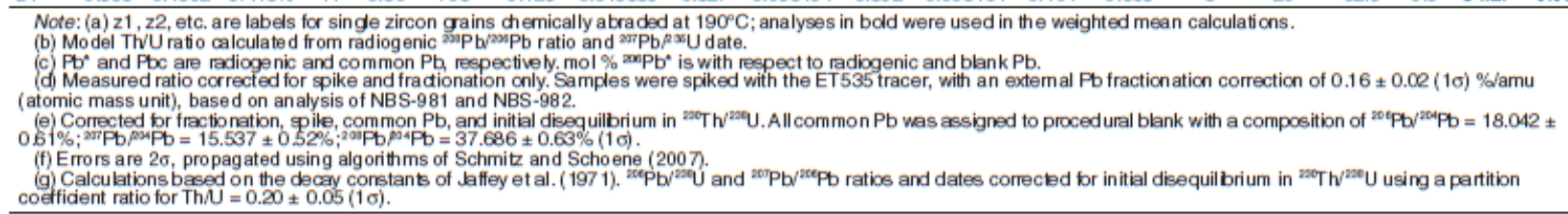 } \\
\hline
\end{tabular}

TABLE 2. PALYNOMORPH COUNTING OF THE CAH1 SECTION

\begin{tabular}{|c|c|c|c|c|c|c|c|c|c|c|c|c|c|}
\hline Sample number & 40 & 41 & 42 & 44 & 46 & 48 & 50 & 52 & 54 & 56 & 58 & 60 & 62 \\
\hline Thickness (m) & 0.20 & 0.65 & 18.05 & 19.50 & 20.50 & 21.45 & 22.45 & 23.40 & 23.12 & 24.10 & 24.80 & 25.65 & 26.55 \\
\hline \multicolumn{14}{|c|}{ MEGATHERMS } \\
\hline Amanoa (Phyllanthaceae) & 1 & 1 & & & & & & & & & & & \\
\hline Buxus bahamensls-type (Buxaceae) & & & 1 & & & & 1 & & & & & & \\
\hline \multicolumn{14}{|c|}{ MEGA-MESOTHERMS } \\
\hline Arecaceae & & 1 & & & 2 & & & & & & & & \\
\hline Dacrydlum-type (Podocarpaceae) & & & 1 & & & & & & & & & & \\
\hline Distyllum (Hamamelldaceae) & & & & & 1 & & 1 & & & & 1 & 3 & \\
\hline Engellhardla (Including Allaroa-type) (Juglandaceae) & 8 & 4 & 2 & 3 & 1 & 2 & 3 & 4 & 5 & 2 & 3 & 4 & 11 \\
\hline llex foribunda-type (Aqulfollaceae) & & & & & & & & 1 & & & & & \\
\hline Mussaenda-tvpe (Rublaceae) & & & & & & & & 1 & & & & & \\
\hline Myrica (Myricaceae) & 2 & 1 & 1 & 2 & & 3 & 1 & 2 & & & 5 & 5 & \\
\hline Myricaceae-type & & & & & 1 & & & & & & & & \\
\hline Rholptelea (Juglandaceae) & & & & & & & 1 & & & & & & \\
\hline Sapindaceae & 1 & & & & & & & & & & & & \\
\hline Sapotaceae & & 1 & & & & & & & & & & & \\
\hline Scladopltys (Scladopltyaceae) & 1 & & 1 & & 1 & & & 1 & & & 1 & 2 & 1 \\
\hline Sindora (Leguminosae) & & & 1 & & & & & & & & & & \\
\hline Glyptostrobus-Taxodlum-type (Cupressaceae) & 28 & 18 & 29 & 17 & 91 & 23 & 12 & 24 & 73 & 25 & 26 & 31 & 39 \\
\hline Sequola-type (Cupressaceae) & 15 & 27 & 40 & 40 & 6 & 88 & 89 & 83 & 26 & 85 & 73 & 56 & 46 \\
\hline Uimaceae & & 1 & & & 2 & & & & & & & & 1 \\
\hline & & & & & & & & & & & & & \\
\hline Cathaya (Pinaceae) & 14 & 31 & 5 & 9 & 10 & 5 & 8 & 9 & 7 & 10 & 7 & 8 & 10 \\
\hline Podocarpus-type (Podocarpaceae) & 3 & 1 & 2 & 16 & 6 & 1 & 2 & 3 & 5 & 2 & & & \\
\hline \multicolumn{14}{|c|}{ MESOTHERMS } \\
\hline Acer (Sapindaceae) & 1 & & & 1 & & & 2 & & & & 1 & 1 & 1 \\
\hline Alnus (Betulaceae) & 3 & 5 & 2 & 15 & 5 & & 2 & 2 & 2 & 6 & & 4 & 2 \\
\hline Betula (Betulaceae) & 1 & 5 & & & 2 & & & & & & & & 1 \\
\hline Carplnus (Betulaceae) & 1 & 9 & 2 & 1 & & & & 1 & & & & 1 & 3 \\
\hline Carplnus orientalls -type (Betulaceae) & & & & 2 & & & & & & & & & \\
\hline Carya (Juglandaceae) & 1 & 5 & 1 & 4 & & 3 & & 2 & & 1 & 1 & 2 & 5 \\
\hline Ericaceae & 26 & 1 & 8 & & & & & 2 & & 1 & 2 & 5 & 2 \\
\hline Fraxlinus (Oleaceae) & 1 & & 1 & & & 1 & & 1 & & & & & \\
\hline Juglans (Juglandaceae) & 1 & & & & & & & & & & & & \\
\hline Liquidambar (Altinglaceae) & 2 & 1 & 1 & & & & & & & & & 1 & \\
\hline Lonicera (Caprlfollaceae) & & & & & & & & & & & & & 1 \\
\hline Ostrya (Betulaceae) & 1 & & & & & & & & & & & & \\
\hline Populus (Sallcaceae) & & 6 & 2 & & & 3 & 1 & 2 & 4 & 1 & & & \\
\hline Pterocarya (Juglandaceae) & & & 1 & & 1 & & & & & & & & 1 \\
\hline Quercus (Fagaceae) & 2 & 3 & 2 & & & 1 & 1 & 3 & & 2 & & 1 & 2 \\
\hline Sallx (Sallcaceae) & & & & & & & 1 & & 1 & & & & \\
\hline Tamartx (Tamaricaceae) & & & & & & 1 & 1 & & & & 1 & & 1 \\
\hline TW a (Malvaceae) & & & 1 & & & & & & & & & & \\
\hline Uimus (UImaceae) & 1 & 1 & 3 & 4 & 1 & 3 & 4 & 3 & 1 & 1 & & 1 & 1 \\
\hline Zelkova (Ulmaceae) & & 3 & & & & & 3 & 1 & & 1 & & & \\
\hline \multicolumn{14}{|c|}{ MESO-MESOTHERMS } \\
\hline Cedrus (Plnaceae) & 3 & & & & & & 1 & & & & & & \\
\hline Faqus (Fagaceae) & & 1 & & & & & & & & & & & \\
\hline Tsuga (PInaceae) & 3 & & 2 & & & & & & & & & 3 & \\
\hline \multicolumn{14}{|c|}{ MICROTHERMS } \\
\hline Ables (PInaceae) & 2 & & & & & & & & & & & & \\
\hline Picea (PInaceae) & 2 & 1 & & & & & & 1 & & & & 1 & \\
\hline
\end{tabular}


TABLE 2. PALYNOMORPH COUNTING OF THE CAH1 SECTION (ContinUed)

\begin{tabular}{|c|c|c|c|c|c|c|c|c|c|c|c|c|c|}
\hline Sample number & 40 & 41 & 42 & 44 & 46 & 48 & 50 & 52 & 54 & 56 & 58 & 60 & 62 \\
\hline Thickness (m) & 0.20 & 0.65 & 18.05 & 19.50 & 20.50 & 21.45 & 22.45 & 23.40 & 23.12 & 24.10 & 24.80 & 25.65 & 26.55 \\
\hline \multicolumn{14}{|c|}{ TAXA WITHOUT PRECISE ECOLOGICAL SIGNIFICANCE } \\
\hline Aqullapollenites (fossil taxon) & & 2 & 2 & & & & & & & & & & \\
\hline Cupressaceae (Cupressus-Juniperus-type) & 23 & 21 & 38 & 41 & 21 & 23 & 24 & 18 & 35 & 24 & 39 & 35 & 23 \\
\hline Plinus diplostellate-type (PInaceae) & 21 & 6 & 2 & 7 & 7 & & 3 & 2 & 4 & 2 & & 2 & 5 \\
\hline Plinus haplostellate-type (PInaceae) & 1 & & & & & & & & & & & & \\
\hline Plinus haploxylon-type (Plnaceae) & & & & & & & & & & & & 1 & \\
\hline Pinaceae (unidentifled pollen grains) & 7 & 17 & 8 & & & 4 & & & & & 6 & 3 & 1 \\
\hline $\begin{array}{l}\text { PInaceae and/or Podocarpaceae (unidentifled } \\
\text { pollen grains) }\end{array}$ & & & & 26 & 17 & & 5 & 3 & 8 & 2 & & & \\
\hline Ranunculaceae & & & & & & & & 1 & & & & & \\
\hline Rosaceae & 2 & & & & & & 1 & 1 & & 2 & & & \\
\hline \multicolumn{14}{|c|}{ WATER PLANTS } \\
\hline Cuphea (Lythraceae) & & & 1 & & & & & 1 & & & & & \\
\hline Lythraceae & 1 & & & & & & & & & & & & \\
\hline Menyanthaceae & & & & & & & 1 & 1 & & & & & 2 \\
\hline Monocotyledon (unidentilled) & 1 & & 1 & & & & & & & & 1 & & \\
\hline Myriophyllum (Haloragaceae) & & & & & 1 & & & 2 & & & & & \\
\hline Onagraceae & & & & & & & & & & & & 1 & \\
\hline Potamogeton (Potamogetonaceae) & & & & & 1 & & & & 1 & & & & \\
\hline Restionaceae & & & & & & & & 4 & & & & & \\
\hline Typha (Typhaceae) & & & & & & & 1 & & & & & & \\
\hline \multicolumn{14}{|c|}{ HERBS } \\
\hline Amaranthaceae & 1 & & & & & & & & & & & & \\
\hline Campanulaceae & & 3 & & & & & & & & & & & \\
\hline Cyperaceae & 3 & 1 & 2 & & & 1 & 1 & 1 & & 1 & & & \\
\hline Llllaceae & 1 & & & & & & 1 & 1 & & & & & \\
\hline Papaveraceae & & & & & & & & & & & & 1 & \\
\hline Poaceae & & 1 & & & & & & & & & & & 1 \\
\hline Rumex (Polygonaceae) & & & 2 & & & & & & & & & & \\
\hline Tromus-type (Ranunculaceae) & & & & 2 & & & & & & & & & \\
\hline Total number of identifled pollen grains & 185 & 178 & 165 & 190 & 177 & 162 & 171 & 181 & 172 & 168 & 167 & 172 & 160 \\
\hline Unidentifled pollen grains & 7 & 16 & 12 & 11 & 7 & 4 & 6 & 3 & 6 & 5 & 4 & 7 & 11 \\
\hline Indeterminable pollen grains & 1 & 1 & & & 3 & & & & & & 1 & 1 & \\
\hline Thermophilous / non-thermophilous taxa ratio & 3.59 & 2.74 & 11.00 & 3.56 & 7.13 & 21.33 & 11.18 & 10.23 & 9.33 & 10.42 & 15.57 & 9.75 & 11.80 \\
\hline \multicolumn{14}{|c|}{ PTERIDOPHYTES } \\
\hline Azolla (Salvinlaceae) microspores & 2 & & 2 & & & & & & & 1 & 1 & & 3 \\
\hline Osmunda (Osmundaceae) & 4 & 14 & 7 & 7 & 2 & 2 & 3 & 2 & 7 & & 9 & 1 & 22 \\
\hline Selaginella (Selaginellaceae) & & & & & & & & & & & & & 1 \\
\hline Unilentifled molonete spores & 15 & 28 & 8 & 6 & 13 & 1 & 2 & 6 & 1 & 1 & & 4 & 13 \\
\hline Unidentilied trilete spores & 10 & 25 & 8 & 8 & & 5 & 1 & 5 & 6 & 2 & 6 & 7 & 13 \\
\hline Unidentifled spores & 18 & 42 & 31 & 15 & 33 & 20 & 19 & 24 & 79 & 15 & 44 & 43 & 52 \\
\hline \multicolumn{14}{|c|}{ BRYOPHYTES } \\
\hline Unidentifled spores & 1 & & 1 & & & & & & & & & & \\
\hline \multicolumn{14}{|c|}{ OTHER PALYNOMORPHS } \\
\hline Fungl & & & & & & & 1 & 1 & & & & & 16 \\
\hline Marine dinoflagellate and acritarch cysts & & 1 & 9 & & 4 & 13 & 3 & 10 & & & 16 & & \\
\hline \multicolumn{14}{|c|}{ REWORKED PALYNOMORPHS } \\
\hline Pollen gralns & 16 & 7 & 15 & 1 & & & 1 & 11 & 1 & 1 & 1 & 4 & 44 \\
\hline Fern spores & 19 & 16 & 31 & & & 1 & 1 & 7 & 1 & 1 & 2 & 6 & 47 \\
\hline Dinoflagellate and acritarch cysts & 1 & 2 & 1 & & & & 1 & 1 & & & & & 6 \\
\hline
\end{tabular}


TABLE 3. PALYNOMORPH COUNTING OF THE CAH2 SECTION

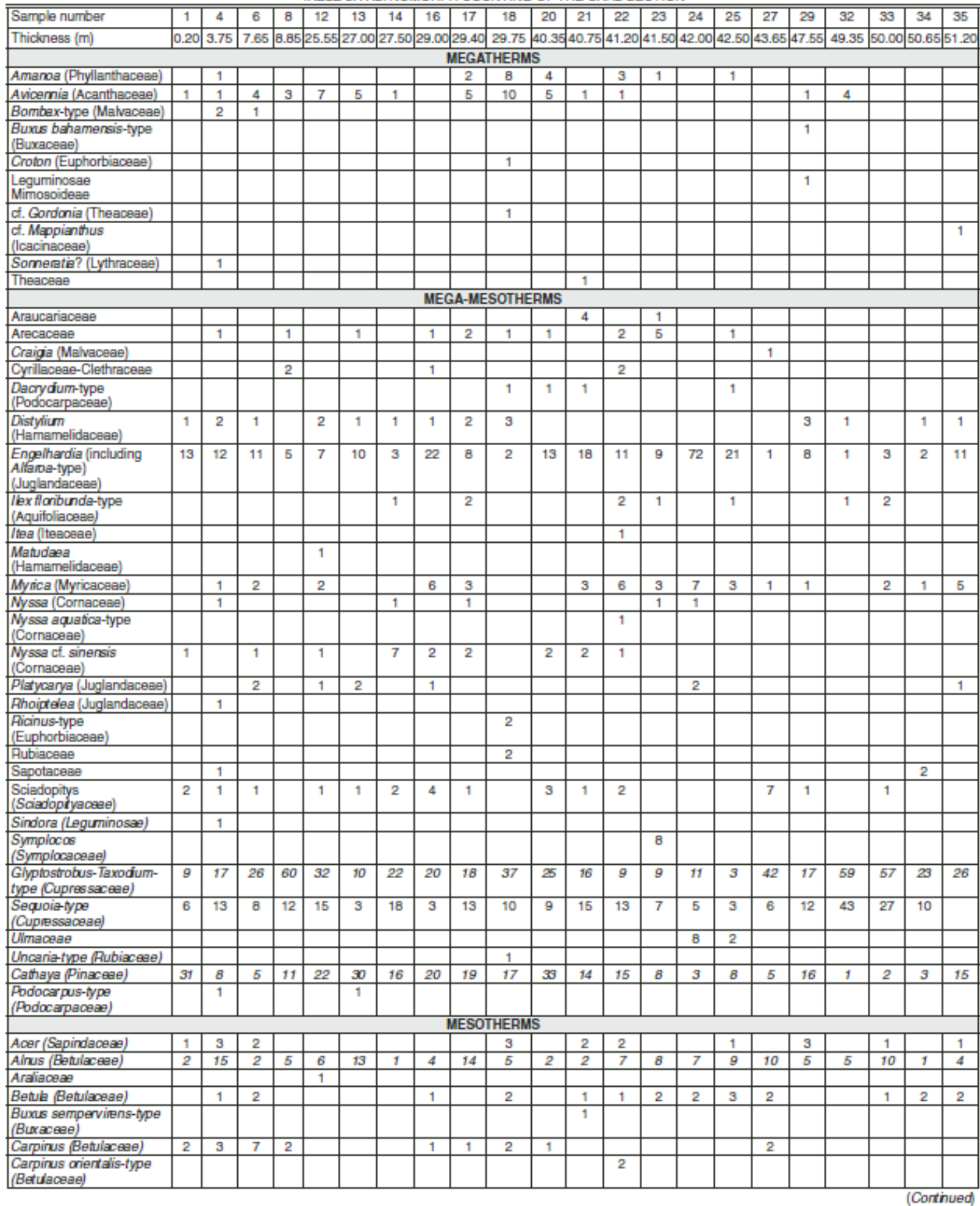


TABLE 3. PALYNOMORPH COUNTING OF THE CAH2 SECTION (Continued)

\begin{tabular}{|c|c|c|c|c|c|c|c|c|c|c|c|c|c|c|c|c|c|c|c|c|c|c|}
\hline Sample number & 1 & 4 & (26 & 8 & 12 & 13 & 14 & 16 & 17 & 18 & 20 & 21 & 222 & 23 & 24 & 25 & 27 & 29 & 32 & 33 & 34 & 35 \\
\hline Thickness (m) & 0.20 & 3.75 & 7.65 & 8.85 & 25.55 & 27.00 & 27.50 & 29.00 & 29.40 & 29.75 & 40.38 & 40.75 & 41.20 & 41.50 & 42.00 & 42.50 & 43.65 & 47.55 & 49.35 & 50.00 & 50.65 & 51.20 \\
\hline Carya (Juglandecae) & 3 & 12 & 12 & 6 & 8 & 6 & 2 & 6 & 1 & 2 & 1 & 6 & 2 & 1 & 1 & 1 & 1 & 2 & 1 & 3 & & 1 \\
\hline $\begin{array}{l}\text { Casuarina } \\
\text { (Casuaninaceag) }\end{array}$ & & & & & & & & & & & & 2 & & & & & & & & & & \\
\hline Celtis (Cannabaceag) & 1 & 1 & 3 & & & & & 1 & & & & 4 & 1 & 1 & & & & 1 & 1 & 1 & & \\
\hline Fraxinus (Oleaceae) & & & & & & & & & & & & & 1 & 1 & & 1 & & & & & & \\
\hline Iex (Aquifoliaceae) & & & & & & & & & & & & & & 1 & & & & & & & & \\
\hline Juglans (Juglandaceae) & & & 1 & & & & & & & & & & & & & & & & & & & \\
\hline $\begin{array}{l}\text { Liquidambar } \\
\text { (Hamamelidaceae) }\end{array}$ & & & 1 & & 1 & & & & 2 & & & & & & & & 1 & & & 1 & & \\
\hline Ostrya (Betulaceae) & & & 2 & & & & & 2 & 1 & 1 & & & & & & & 2 & 2 & 1 & & & 2 \\
\hline $\begin{array}{l}\text { Parthenocissus cf. } \\
\text { herryana (Vítacaae) }\end{array}$ & & & & & & & & & & 1 & & & & & & & & & & 1 & & \\
\hline Phamnaceas & & 1 & & & 1 & & & & & & & & & & & & & & & & & \\
\hline Rhus (Anacardiecaae) & & & & & & & & & & & & & 1 & & & & & & & & & \\
\hline Saíx (Salicacam) & 1 & 1 & 2 & 1 & & 5 & 1 & & & & & & & & & & & & & & & 1 \\
\hline Tamanxx (Tamaricaceae) & & & 1 & & & & & & & & & & & & & & & & & & & \\
\hline Tilia (Maivacaae) & & 1 & & & 1 & & & & & & & & & & & & & & 1 & 2 & & \\
\hline Uimus (Nimacaae) & 3 & 6 & 5 & 13 & 3 & 1 & 2 & 1 & 1 & 1 & 2 & & 1 & 9 & 3 & 5 & 4 & 1 & 2 & & 2 & 3 \\
\hline Vibumum (Adaxacaae) & & & 1 & & & & & & & & & & & & & & & & & & & \\
\hline Zelkova (Uhaceae) & & 5 & 2 & 2 & & & & 1 & & & & 2 & & & 3 & 2 & & & & 1 & & \\
\hline \multicolumn{23}{|c|}{ MESO-MICAOTHERMS } \\
\hline Cedins (Pinaceae) & & & & & & & & & & & & & 2 & & & & & & & & & \\
\hline Fagus (Fagaceae) & 1 & & & 1 & 3 & 1 & & 3 & 2 & & 2 & 2 & 2 & 1 & & & 1 & & & & & \\
\hline Tsuga (Pinaceae) & 6 & & & & & 9 & 2 & & 2 & & 2 & & 3 & 1 & & & 2 & 9 & & & 11 & 13 \\
\hline \multicolumn{23}{|c|}{ MICROYTHERMS } \\
\hline $\begin{array}{l}\text { Pinus haplostelate-type } \\
\text { (Pinaceae) }\end{array}$ & & & & & & & & & & & 1 & 1 & & & & 1 & & & & & & \\
\hline $\begin{array}{l}\text { Pinus haploxylon-type } \\
\text { (Pinaceae) }\end{array}$ & & 1 & 1 & & 2 & 3 & & 2 & & 3 & 2 & & & & 1 & & & 1 & & & & 2 \\
\hline $\begin{array}{l}\text { Pinaceae (unidentified } \\
\text { pollen grains) }\end{array}$ & 13 & 9 & 8 & 11 & 2 & 4 & 6 & 2 & 3 & 4 & 15 & 7 & 2 & 4 & 1 & 6 & & 9 & & & 3 & \\
\hline $\begin{array}{l}\text { Pinaceae and } \\
\text { or Podocarpaceae } \\
\text { (unidentified pollen grains) }\end{array}$ & & & & & & & & & & & & & & & & & & & & & & 17 \\
\hline Aanunculacaae & 1 & 1 & & & & & 5 & & 1 & & 1 & 1 & 1 & & & & & & & & & \\
\hline Rosaceae & 1 & 3 & 2 & 3 & & & & 1 & 1 & 2 & 2 & 2 & 3 & 5 & & 7 & & & & 1 & & 1 \\
\hline Autaceee & & 1 & & & & & & & & & & & & & & & & & & & & \\
\hline \multicolumn{23}{|c|}{ WATER PLANTS } \\
\hline Alisma (Alismataceae) & & & & 1 & & & & & & 5 & & & 2 & & & & 1 & & & & & \\
\hline Cuphea (Lythraceae) & & & & & & & & & & & & & & & & & & 1 & 3 & 1 & & \\
\hline Menyanthaceae & 1 & & 2 & & & & & & 1 & & & & & & & & & & & & & \\
\hline $\begin{array}{l}\text { Monocotyledon } \\
\text { (unidentified) }\end{array}$ & & & & & & & & & & & & & 1 & & & & & & & & & \\
\hline $\begin{array}{l}\text { Potamogeton } \\
\text { (Potamogetonaceae) }\end{array}$ & & & & & & & & & & & & 1 & & & & & & & & & & \\
\hline
\end{tabular}


TABLE 3. PALYNOMORPH COUNTING OF THE CAH2 SECTION (Continued)

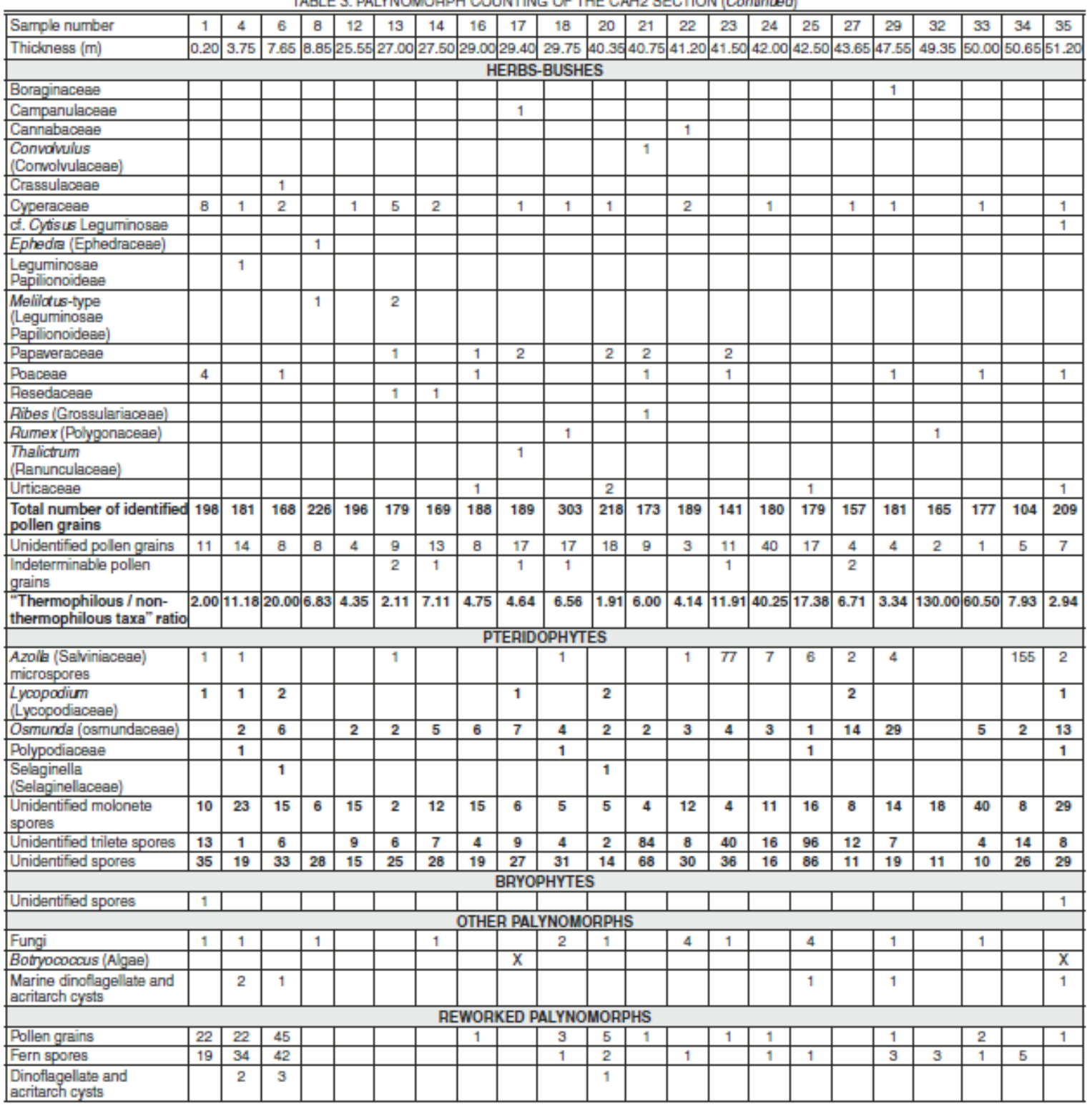


TABLE 4. CLIMATIC CONDITIONS RECORDED FOR THE EOCENE AROUND THE ARCTIC BASIN

\begin{tabular}{|c|c|c|c|c|c|c|c|c|}
\hline Location & Flg.1 & $\begin{array}{l}\text { MAT } \\
\left({ }^{\circ} \mathrm{C}\right)\end{array}$ & $\begin{array}{l}\text { MART } \\
\left({ }^{\circ} \mathrm{C}\right)\end{array}$ & $\begin{array}{c}\mathrm{CMMT} \\
\left({ }^{\circ} \mathrm{C}\right)\end{array}$ & $\begin{array}{c}\text { WMMT } \\
\left({ }^{\circ} \mathrm{C}\right)\end{array}$ & $\begin{array}{c}\text { MAP } \\
(\mathrm{mm} / \mathrm{yr})\end{array}$ & Age & Reterence \\
\hline $\begin{array}{l}\text { Axel Helberg } \\
\text { Island }\end{array}$ & 4 & $13-15$ & - & 4 & - & $>1200$ & Middle Eocene & Greenwood et al., 2010 \\
\hline $\begin{array}{l}\text { Axel Helberg } \\
\text { Island }\end{array}$ & 4 & 13.2 & - & - & - & - & Middle Eocene & Jahren et al, 2003 \\
\hline Gulf of Alaska & 9 & $20-25$ & - & $>13$ & - & - & Eocene & Wolte, 1977 \\
\hline $\begin{array}{l}\text { Norweglan- } \\
\text { Greenland Sea }\end{array}$ & 5 & 14 & - & $>5$ & $18-24$ & -1200 & $\begin{array}{l}\text { Late Early-Middle } \\
\text { Eocene }\end{array}$ & Eldrett et al., 2009 \\
\hline $\begin{array}{l}\text { Ellesmere Island- } \\
\text { Axel Helberg Is }\end{array}$ & $3-4$ & $12-15$ & $20-25$ & $0-4$ & $>25$ & - & $\begin{array}{l}\text { Late Paleocene- } \\
\text { middle Eocene }\end{array}$ & Basinger et al., 1994 \\
\hline Ellesmere Island & 3 & 8 & $16.5-19$ & $0-3.5$ & $19-20$ & - & Early Eocene & Eberle et al., 2010 \\
\hline Ellesmere Island & 3 & 8.2 & 14 & -2 & - & - & Early Eocene & Greenwood et al., 1995 \\
\hline Ellesmere Island & 3 & $\begin{array}{l}12.7-14.4 \\
8.5-12.4^{*} \\
9.5-12.1^{\dagger}\end{array}$ & - & $3.6-4.6$ & $22-24.4$ & $2200-2400$ & Earty Eocene & West et al., 2015 \\
\hline Lomonosov & 7 & $18-20$ & - & - & - & - & Earty Eocene & Wellers et al., 2007 \\
\hline $\begin{array}{l}\text { New SIberlan } \\
\text { Island }\end{array}$ & 8 & $16-21$ & - & $5.5-14$ & $25-28$ & $1100-1400$ & Early Eocene & Suan et al., 2017 \\
\hline $\begin{array}{l}\text { Nelson Fleld, } \\
\text { Central North } \\
\text { Sea }\end{array}$ & 6 & $15-20$ & - & $7-12$ & $22-26$ & $1100-1500$ & Early Eocene & Eldrett et al., 2014 \\
\hline Brackett Basin & 2 & - & - & - & - & $1250-1300$ & Middle Paleocene & Greenwood et al., 2010 \\
\hline
\end{tabular}

